\title{
Role of geochemical alteration on the formation of secondary Zr- and U-bearing minerals in El Atshan trachyte, central Eastern Desert, Egypt
}

\author{
Hamdy H. ABD EL-NABY,*** \\ "King Abdulaziz University, Faculty of Earth Sciences, \\ P.O. Box 80206, Jeddah 21589, Saudi Arabia \\ ${ }^{* *}$ Nuclear Materials Authority, P.O. 530 El-Maadi, Cairo, Egypt
}

\begin{abstract}
El Atshan area, situated in the central Eastern Desert of Egypt, is a good location for studying the influence of high- and low- $T$ alterations on the formation of $\mathrm{Zr}$ - and $\mathrm{U}$-bearing minerals within a trachyte sill. These minerals are mainly represented by an unidentified secondary Zr-rich silicate mineral, betafite, and liandratite. The unidentified $\mathrm{Zr}$-rich silicate mineral is considered to be an alteration product of the precursor zirconolite during high- $T$ alteration. This is indicated by the changes in the composition marked by an increase in the amount of hydration $\left(\mathrm{H}_{2} \mathrm{O}\right)$, Si, and $\mathrm{U}$ and a decrease in the amount of $\mathrm{Ca}, \mathrm{Ti}, \mathrm{Nb}$, and $\mathrm{Fe}$. The morphology of this unidentified mineral is similar to that of zirconolite. For seven oxygen atoms, the calculated formula of the unidentified $\mathrm{Zr}$-rich silicate mineral is $\left(\mathrm{Si}_{1.45} \mathrm{U}_{0.18} \mathrm{Ca}_{0.32} \mathrm{~Pb}_{0.01} \mathrm{Nb}_{0.06} \mathrm{Zr}_{1.18} \mathrm{Hf}_{0.01} \mathrm{Fe}_{0.06} \mathrm{Al}_{0.08} \mathrm{Ti}_{0.11} \mathrm{P}_{0.09} \mathrm{Y}_{0.05} \mathrm{REE}_{0.09}\right)_{\Sigma 3.7} \mathrm{O}_{7}$. With more extensive alteration, it was found that the unidentified secondary $\mathrm{Zr}$-rich silicate mineral was unstable and it underwent re-equilibration with U-rich fluid, which led to alterations in betafite. The two possible mechanisms responsible for the alteration of the unidentified $\mathrm{Zr}$-rich silicate mineral to betafite are as follows: (1) the dissolution of the unidentified $\mathrm{Zr}$-rich silicate mineral and precipitation of betafite and (2) the ion-exchange between partially to fully amorphized zones and the U-rich fluid. Such alteration is indicated by a marked increase in the amount of $\mathrm{U}, \mathrm{Ti}$, and $\mathrm{Nb}$ and a decrease in the amount of $\mathrm{Zr}, \mathrm{Si}, \mathrm{Ca}, \mathrm{P}, \mathrm{Y}$, and $\Sigma \mathrm{REE}$. The single substitution of $\mathrm{U}^{4+} \leftrightarrow \mathrm{Zr}^{4+}$ and the coupled substitution of $\left(\mathrm{U}^{4+}+\mathrm{Ti}^{4+}+\mathrm{Nb}^{5+}\right) \leftrightarrow\left(\mathrm{Zr}^{4+}+\mathrm{Si}^{4+}+\mathrm{Ca}^{2+}+\mathrm{P}^{5+}+\mathrm{Y}^{3+}+\Sigma \mathrm{REE}^{3+}\right)$ appear to be the main causes for the formation of betafite. For $2.00 \mathrm{~B}$-site cations, the calculated formula of the betafite is ${ }^{A}\left(\mathrm{U}_{0.44} \mathrm{Ca}_{0.25} \mathrm{REE}_{0.05} \mathrm{Y}_{0.03} \mathrm{~Pb}_{0.02}\right)_{\Sigma 0.79}{ }^{B}\left(\mathrm{Si}_{0.79} \mathrm{Zr}_{0.69} \mathrm{Ti}_{0.23} \mathrm{Nb}_{0.12} \mathrm{Al}_{0.06} \mathrm{Fe}_{0.05} \mathrm{P}_{0.03} \mathrm{~V}_{0.02} \mathrm{Hf}_{0.01}\right)_{\Sigma 2.0} \mathrm{O}_{7}$. Betafite was altered to liandratite in the late low $-T$ alteration stage. For $2.00 \mathrm{Nb}$-site cations, the calculated formula of the liandratite is ${ }^{U}\left(\mathrm{U}_{1.35} \mathrm{Ca}_{0.41} \mathrm{~Pb}_{0.04} \mathrm{REE}_{0.04} \mathrm{Y}_{0.01}\right)_{\Sigma 1.86}{ }^{N b}\left(\mathrm{Ti}_{0.67} \mathrm{Si}_{0.46} \mathrm{Nb}_{0.40} \mathrm{Zr}_{0.26} \mathrm{e}_{0.09} \mathrm{~V}_{0.08} \mathrm{Al}_{0.03} \mathrm{Ta}_{0.01}\right)_{\Sigma 2.0} \mathrm{O}_{8}$. Among different uranium complexes, the influence of fluoride on the solubility and mobility of uranium is confirmed.
\end{abstract}

Keywords: Egypt, Unidentified Zr-rich silicate mineral, Betafite, Liandratite, Alteration

\section{INTRODUCTION}

Natural pyrochlores are grouped into three types: pyrochlore (niobium-rich), microlite (tantalum-rich), and betafite (titanium- and uranium-rich). The simplified general formula of the pyrochlore group is $\mathrm{A}_{2} \mathrm{~B}_{2} \mathrm{X}_{7} \mathrm{Y}$. $\mathrm{nH}_{2} \mathrm{O}$, where $\mathrm{A}$ denotes $\mathrm{Ca}, \mathrm{Na}$, actinides, rare earth elements (REEs), $\mathrm{Ba}, \mathrm{Sr}, \mathrm{Bi}, \mathrm{Pb}$, and $\mathrm{U}$; $\mathrm{B}$ denotes $\mathrm{Nb}, \mathrm{Ta}$, $\mathrm{Ti}, \mathrm{Zr}, \mathrm{Sb}, \mathrm{W}$, and $\mathrm{Fe}$; $\mathrm{X}$ denotes $\mathrm{O}$ and $\mathrm{OH}$; and $\mathrm{Y}$ denotes $\mathrm{O}, \mathrm{OH}$, and $\mathrm{F}$ (Hogarth, 1977). Some alteration in natural betafite is due to the loss of relatively soluble cations such as $\mathrm{Na}, \mathrm{K}, \mathrm{Ca}$, and $\mathrm{U}$ (Lumpkin and Ewing,

doi:10.2465/jmps.080506

H.H. Abd El-Naby, hhabdel@yahoo.com Corresponding author
1985, 1996; Lumpkin et al., 1994). The fluids responsible for alteration range from dense, supercritical magmatic fluids to mixed magmatic-meteoric fluids to groundwater of low ionic strength. Studies of natural pyrochlore have provided a considerable amount of information on the aspects of the long-term performance of pyrochlore phases in titanate-based ceramic nuclear wastes, including tailored ceramics (Harker, 1988) and Synroc (Ringwood et al., 1988; Ball et al., 1989).

In contrast, the chemical alteration of natural zirconolite is relatively uncommon and the Th and $\mathrm{U}$ contents remain almost constant (Lumpkin et al., 1994). The limited corrosion of zirconolite has been documented in a natural hydrothermal vein system at temperatures of 


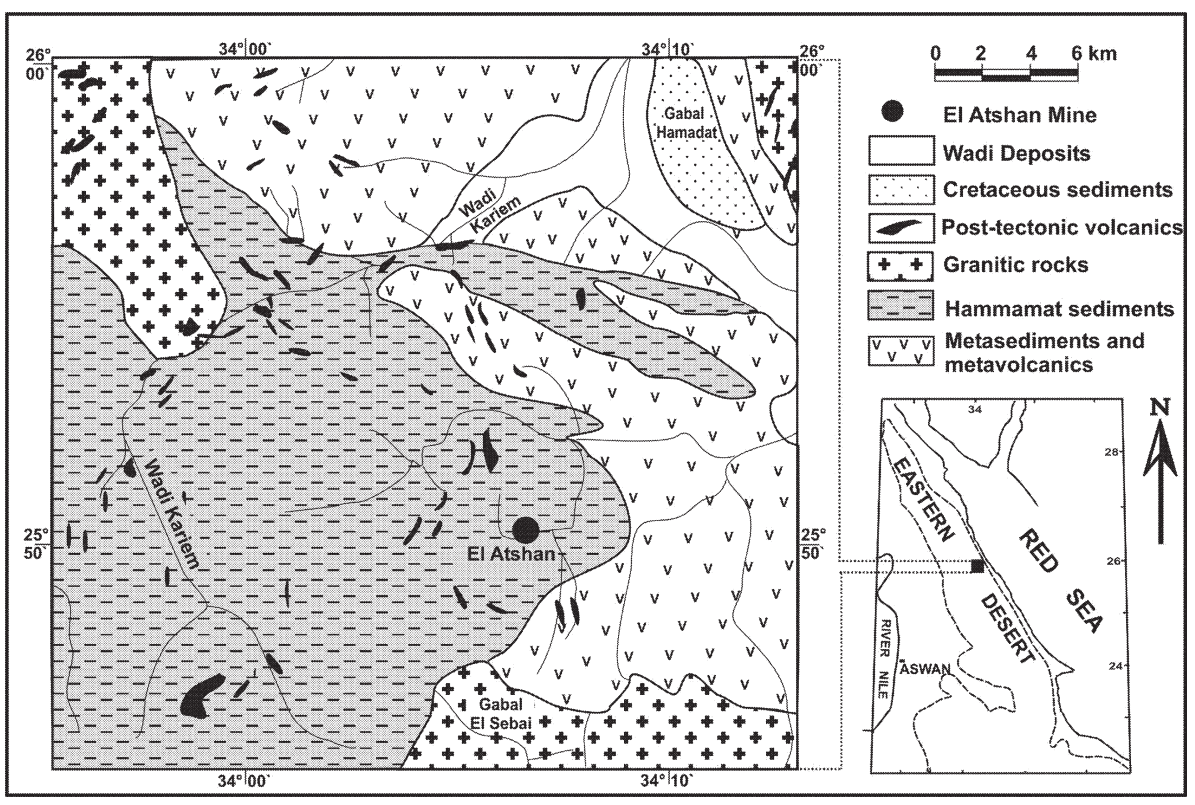

Figure 1. Geological map of El Atshan area.
$500-600{ }^{\circ} \mathrm{C}$ by a relatively acidic aqueous fluid with significant concentrations of $\mathrm{H}_{2} \mathrm{~S}, \mathrm{HF}$, and $\mathrm{HCl}$ (Gieré and Williams, 1992). The complete replacement of zirconolite by zircon, sphene, and rutile has been observed in metamorphic systems at very high temperatures of $620-680{ }^{\circ} \mathrm{C}$ (Pan, 1997). Several other examples of zirconolite alteration have been presented by Hart et al. (1998), but none of these appear to involve significant losses of actinide elements. Williams et al. (2001) have studied zirconolite from 19 carbonatite occurrences. Zirconolite displays varying degrees of alteration that ranges from incipient minor effects to major corrosion, recrystallization, and complete replacement by an unidentified actinide-rich (ACT), $\mathrm{Ba}, \mathrm{Ti}, \mathrm{Zr}$, and $\mathrm{Nb}$ silicate phases.

El Atshan is a good location for studying the influence of high and low- $\mathrm{T}$ alteration on the formation of $\mathrm{Zr}^{-}$ and U-bearing minerals within volcanic rocks. These rocks have previously been recognized as bostonite (El Hazek, 1968; Attawiya, 1971; Hussein and El Kassas, 1972). Recently, Dawood et al. (2004) classified these rocks as trachyte on the basis of their geochemical characteristics. However, the term trachyte is used in the present study that refers to the mineralized volcanic rock in El Atshan area. Presence of some primary ore bodies have been reported in this trachyte by many authors (Obrenovic et al., 1966; El Hazek, 1968). This primary uranium mineral is represented by coffinite and pitchblende with some sulfide minerals such as galena, sphalerite, pyrite, and chalcopyrite. The secondary uranium minerals are represented by uranophane, kasolite, soddyite, gummite, schoepite, schroeckingerite, rutherfordine, zippeite, and uranopilite (Attawiya, 1971). However, only soddyite, kasolite, and uranophane have been confirmed to be present in $\mathrm{El}$ Atshan (e.g., Osmond et al., 1999; Dawood et al., 2004).

In this paper, I report the first documented occurrence of an unidentified secondary Zr-rich silicate mineral, betafite, and liandratite in the trachyte of the El Atshan area, central Eastern Desert, Egypt. The main objectives of the present study are to (1) characterize the chemical composition of uranium-bearing minerals in El Atshan area, (2) establish a general chemical framework for the interaction of $\mathrm{Zr}^{-}$and $\mathrm{U}^{-}$-bearing minerals with high- and low- $T$ fluids, and (3) present a genetic model for this uranium mineralization.

\section{GEOLOGICAL BACKGROUND}

The geology of the El Atshan area has been investigated by Obrenovic et al. (1966), Hussein and El Kassas (1972), Osmond et al. (1999), and Dawood et al. (2004). The main rock units are (from older to younger) metasediments, metavolcanics, Hammamat sediments, granites, and post-tectonic volcanics (Fig. 1). The post-tectonic volcanics are represented by trachyte, felsite, granite porphyry, quartz veins, and less common basic rocks. The alkaline trachyte dikes and sills are the most predominant volcanic rocks. The age of the trachyte is $273 \pm 20$ m.y. (Late Carboniferous to Early Permian, El Manharawy, 1972). Similar ages were reported for volcanic dikes of the Wadi Kariem area (Sayyah et al., 1978). Trachyte forms sills, dikes, and sometimes plugs and cone-like masses of variable thickness. Uranium mineralization occurring at the El Atshan area is mainly associated with a trachyte sill that intruded the foliated Hammamat sedi- 

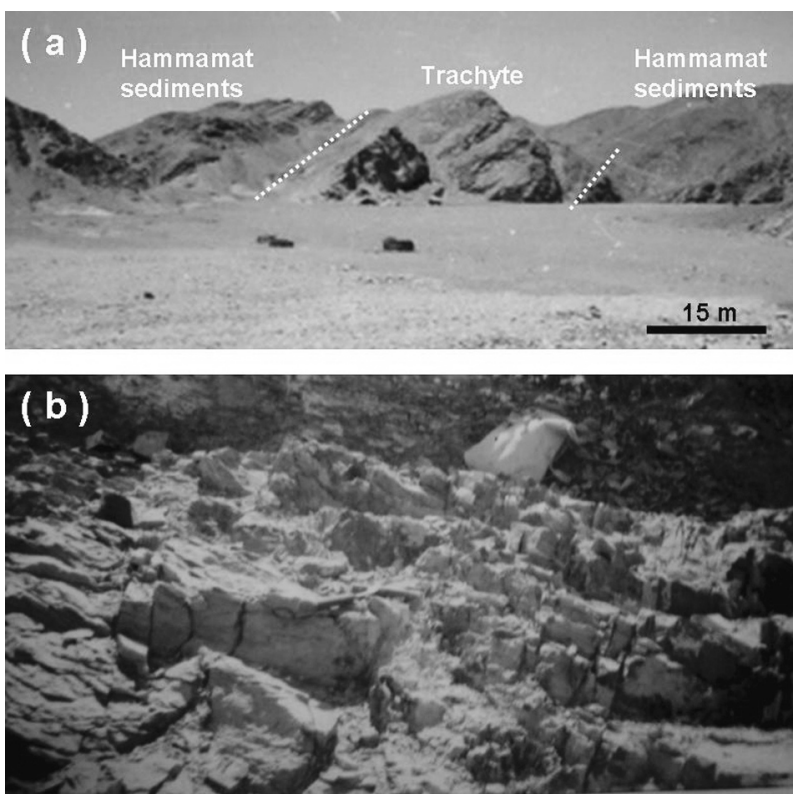

Figure 2. (a) Image showing the trachyte sill intruded in Hammamat sediments. (b) Image showing fissures and fractures in the trachyte sill.

ments (Fig. 2a). This sill extends for approximately 1.5 $\mathrm{km}$ and has a variable thickness (average: $28 \mathrm{~m}$ ). It strikes $\mathrm{N} 26^{\circ} \mathrm{E}$ and has a variable dip to the NW, ranging from $20^{\circ}$ to $45^{\circ}$. This sill is affected by some faults, joints, and fractures in different directions (Fig. 2b); however, the most predominant ones are striking in the NW-SE and NE-SW directions. The fractured rock is usually altered, and most of the joints and fractures are stained with alteration products, including iron, manganese oxides, and clay minerals. Uranium mineralization is generally controlled by these structures, where they fill some tension fractures that are connected to the contact zone between the trachyte sill and the surrounding foliated Hammamat sediments. The upper contact is generally more mineralized than the lower one. The hydrothermal alteration accompanying the deposition of uranium in the host trachyte consists of hematitization, kaolinitization, and carbonatization. The alteration occurs in narrow zones, $0.1-1.0 \mathrm{~cm}$ wide, along the margins of uranium mineralized veinlets and disseminated in the host trachyte. Hematitization is the most distinct style of alteration. The alteration of rock forming minerals is represented by sericite and clay minerals after feldspars, and limonite, goethite, and hematite after magnetite and iron-bearing sulfides. Calcite forms in the altered host rock as disseminations and veins along fractures. Textural evidence shows that the deposition of carbonate minerals was due to syn- and post-mineralization. Similarly, the foliated Hammamat sediment beds are altered along their contacts, faults, and fractures.

The trachyte rock is massive, fine grained, and buff in color. The weathered parts are creamy yellow and sometimes brown in color. The trachyte rocks of the El Atshan area are fine grained (average grain size of approximately $0.5 \mathrm{~mm}$ ) and holocrystalline; however, small amounts of secondary chalcedony or cryptocrystalline quartz are also present in the rocks. The rocks consist mainly of alkali feldspars (anorthoclase and orthoclase), which form around $90 \%$ of the entire rock. Anorthoclase is generally lath-shaped, highly altered, and sericitized, whereas orthoclase occurs as irregular disseminated grains in the matrix and is relatively less altered. Quartz also exists in small amounts not more than $5 \%$ of the rock. It is present in the groundmass filling the interstices. The other constituents are ferromagnesian minerals that are mainly represented by chlorite, which is an alteration product of pyroxenes and amphiboles. Hornblende and aegirine are also present; they are generally obscured due to intense hematitization. The heavy minerals present in the trachyte are non-opaques, opaques, and uranium minerals. The non-opaque minerals are represented by zircon, betafite, apatite, titanite, and fluorite. The opaque minerals are mainly represented by galena, pyrite, chalcopyrite, and sphalerite. They form thin veinlets, fracture fillings, and disseminated grains around the mineralized fractures. In the highly altered parts, the sulfides show partial alteration to iron oxides, especially hematite and limonite. The trachyte is characterized by subtrachytic texture, where the feldspars laths are arranged in a parallel to subparallel orientation. Sometimes, the rock shows porphyritic texture where feldspars are relatively coarse-grained embedded in a microcrystalline groundmass of feldspars, quartz, and iron oxides. The trachyte is sheared and brecciated in some parts; the resulting fractures are filled with uranium minerals deposited from solutions.

Dawood et al. (2004) studied the geochemistry of the trachyte in the study area. They concluded that this rock was subjected to two phases of alteration. The early stage of hydrothermal alteration included argillization, dissolution of iron-bearing sulphides, formation of iron-oxy hydroxides, and corrosion of primary uranium minerals. The second phase of alteration occurred near the surface when the late-stage hydrothermal fluids cooled to the temperature of meteoric water and possibly mixed with it; the $\mathrm{pH}$ of the fluids became more alkaline, and at these conditions, $\mathrm{U}$ and $\mathrm{Eu}$ were precipitated into the fracture system, mainly being adsorbed on the clay minerals and probably being co-precipitated with iron oxy-hydroxides. The disequilibrium state of the secondary uranium minerals in the El Atshan area is reported by many authors (Hussein et al., 1970; Osmond et al., 1999). 


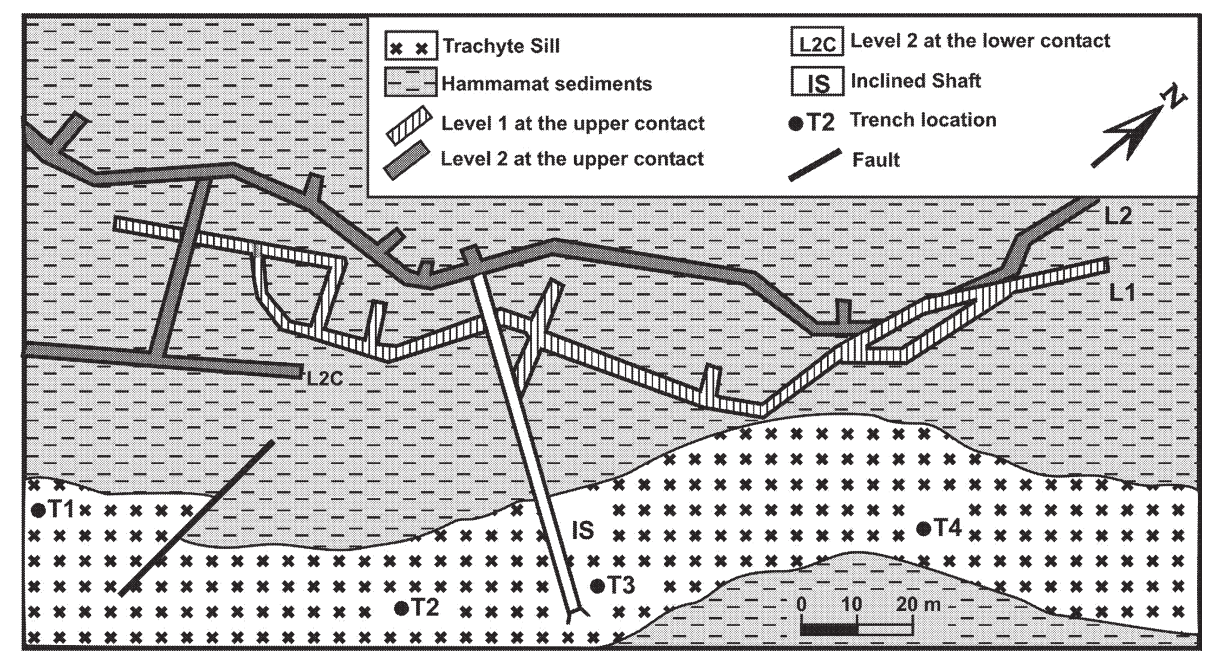

Figure 3. Sketch diagram showing the trench locations and the main levels of the El Atshan mine (after El Hazek, 1968).

\section{ANALYTICAL METHODS}

Eight uranium ore samples were collected from four trenches (T1, T2, T3, and T4) and from an inclined shaft at the El Atshan mine (Fig. 3). The ore samples were scraped from their host rock and their color ranged from pale yellow to brownish yellow, depending on the degree of iron and manganese contamination. After mounting and polishing of the scrapped grains, a JEOL JEE-400 Vacuum Evaporator was used to coat the samples with a carbon layer prior to the analysis. Morphological and textural details of the grains were investigated at a higher magnification, as indicated in the backscattered electron images (BSE) and X-ray compositional mapping presented in this study. The qualitative composition of the grains was initially determined using wavelength-dispersive spectral line scans (WDS) on a JEOL JXA-8900 Electron Probe Microanalyzer (EPMA) available at the Institut für Geowissenschaften -Mineralogie und Geodynamik- der Universität Tübingen, Germany. Quantitative analyses of $\mathrm{Zr}^{-}$and U-bearing minerals were performed on the same machine. The analytical conditions were as follows: the accelerating voltage was $15 \mathrm{kV}$, the beam current was 10-20 nA, and the beam diameter was 1-2 $\mu \mathrm{m}$. The standards used were a combination of well-characterized natural minerals, synthetic compounds, and pure metals. Data reduction for the various elements was performed by considering the matrix corrections between the standards and the samples and the analytical parameters. Errors in microprobe analyses due to counting statistics are less than $1 \%$ for uranium and thorium but slightly larger for other elements.

\section{MINERAL CHEMISTRY}

\section{Unidentified secondary Zr-rich silicate mineral}

The unidentified secondary Zr-rich silicate mineral in the trachyte in the El Atshan area is usually accompanied by betafite $\left(\mathrm{CaUTi}_{2} \mathrm{O}_{7}\right)$ and liandratite $\left[\mathrm{U}(\mathrm{Nb}, \mathrm{Ta})_{2} \mathrm{O}_{8}\right]$. None of these minerals have been previously reported. They are reported herein as the first documented occurrence of $\mathrm{Zr}-$ and U-bearing minerals in the trachyte of the El Atshan area. The morphology, mode of occurrence, and paragenetic association of the unidentified $\mathrm{Zr}$-rich silicate mineral are illustrated in a series of BSE images (Figs. 4-6). At high magnification, most grains appear to have a consistent prismatic shape (Fig. 4). However, some grains were found to have an irregular shape (Fig. 5). Textural observations indicate that $\mathrm{Zr}$-rich betafite replaces the unidentified Zr-rich silicate mineral (Figs. 4 and 5). However, further studies using different techniques [e.g., X-ray diffraction (XRD) and transmission electron microscopy (TEM)] are required for the characterization of this unidentified $\mathrm{Zr}$-rich silicate mineral.

Fifty electron microprobe analyses were performed with the grains of the unidentified secondary $\mathrm{Zr}$-rich silicate mineral (Table 1). $\mathrm{ZrO}_{2}, \mathrm{SiO}_{2}, \mathrm{UO}_{2}$, and $\mathrm{CaO}$ were found to be the essential constituents, whereas $\mathrm{Nb}_{2} \mathrm{O}_{5}$, $\mathrm{TiO}_{2}, \mathrm{Y}_{2} \mathrm{O}_{3}, \mathrm{Ce}_{2} \mathrm{O}_{3} \mathrm{Gd}_{2} \mathrm{O}_{3}, \mathrm{P}_{2} \mathrm{O}_{5}, \mathrm{FeO}$, and $\mathrm{Al}_{2} \mathrm{O}_{3}$ were the minor constituents. Negligible amounts $(<1 \mathrm{wt} \%)$ of $\mathrm{PbO}$, $\mathrm{HfO}_{2}$, and $\mathrm{Ta}_{2} \mathrm{O}_{5}$ were also measured (Table 1). The concentration of $\mathrm{ThO}_{2}$ is very low and varies from 0.04 to 0.18 with an average of $0.09 \mathrm{wt} \%$. The formula of the unidentified $\mathrm{Zr}$-rich silicate mineral was calculated on the basis of seven oxygen atoms. The resulting chemical formula is $\left(\mathrm{Si}_{1.45} \mathrm{U}_{0.18} \mathrm{Ca}_{0.32} \mathrm{~Pb}_{0.01} \mathrm{Nb}_{0.06} \mathrm{Zr}_{1.18} \mathrm{Hf}_{0.01} \mathrm{Fe}_{0.06} \mathrm{Al}_{0.08} \mathrm{Ti}_{0.11}\right.$ $\left.\mathrm{P}_{0.09} \mathrm{Y}_{0.05} \mathrm{REE}_{0.09}\right)_{\Sigma 3.7} \mathrm{O}_{7}$.

A similar unidentified secondary $\mathrm{Zr}$-rich silicate 

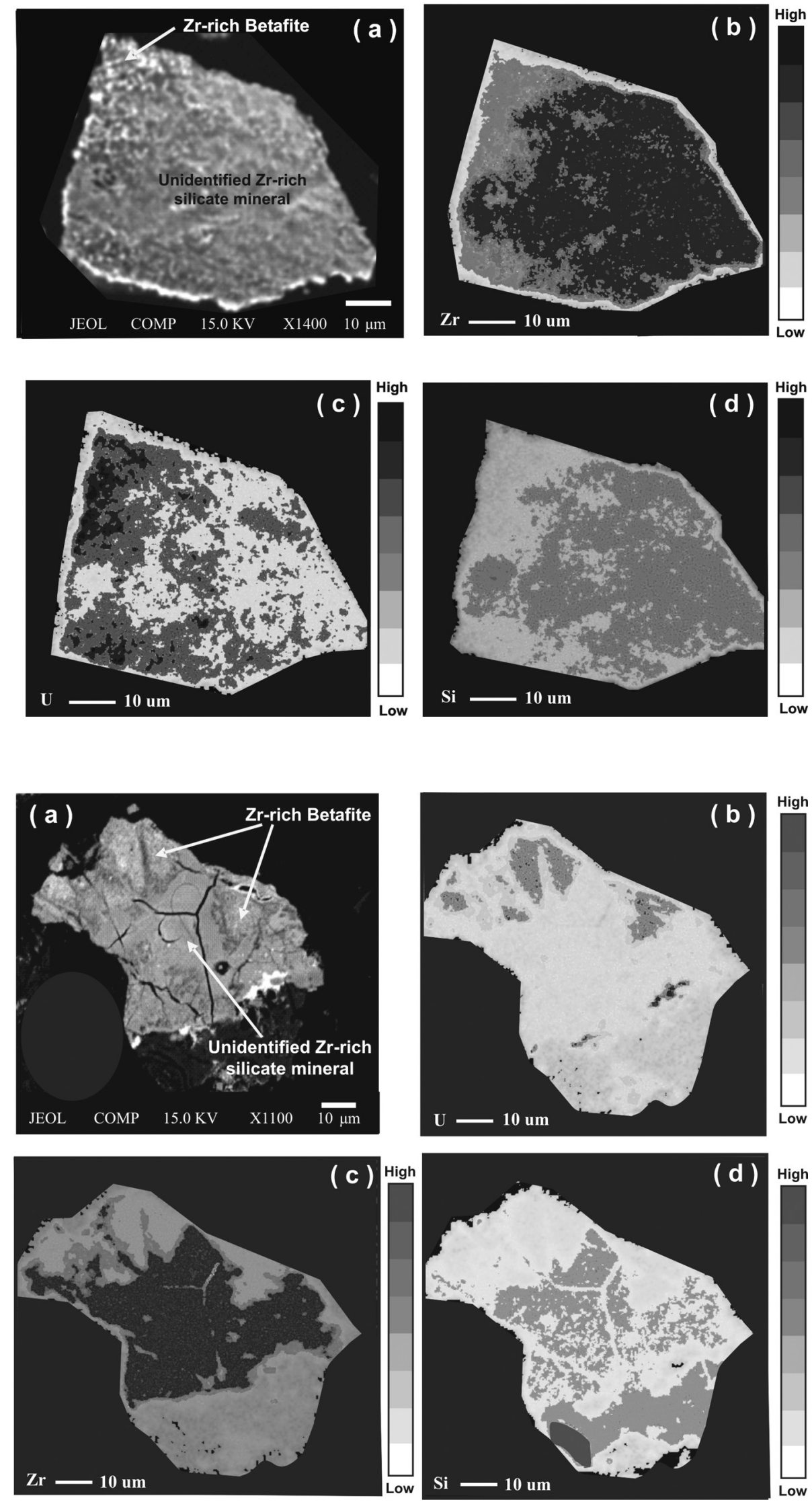

Figure 4. (a) BSE image of the unidentified secondary $\mathrm{Zr}$-rich silicate mineral in the trachyte of the El Atshan area. The crystal shows the common prismatic form of the precursor zirconolite. It altered to $\mathrm{Zr}$-rich betafite near its margins. (b), (c), and (d) X-ray maps showing the distribution of $\mathrm{Zr}$, $\mathrm{U}$, and $\mathrm{Si}$, respectively, in the crystal of image "a." They reflect an increase in the amount of $\mathrm{Zr}$ and $\mathrm{Si}$ and a decrease in the amount of $\mathrm{U}$ in the unidentified $\mathrm{Zr}$-rich silicate mineral relative to the $\mathrm{Zr}^{-}$ rich betafite.
Figure 5. (a) BSE image for the unidentified $\mathrm{Zr}$-rich silicate mineral with a Zr-rich betafite rim. (b), (c), and (d) X-ray maps showing the distribution of $\mathrm{U}, \mathrm{Zr}$, and $\mathrm{Si}$, respectively, in the crystal of image "a." They reflect a decrease in the amount of $\mathrm{Zr}$ and $\mathrm{Si}$ and an increase in the amount of $U$ after the alteration of the unidentified $\mathrm{Zr}$-rich silicate mineral. 

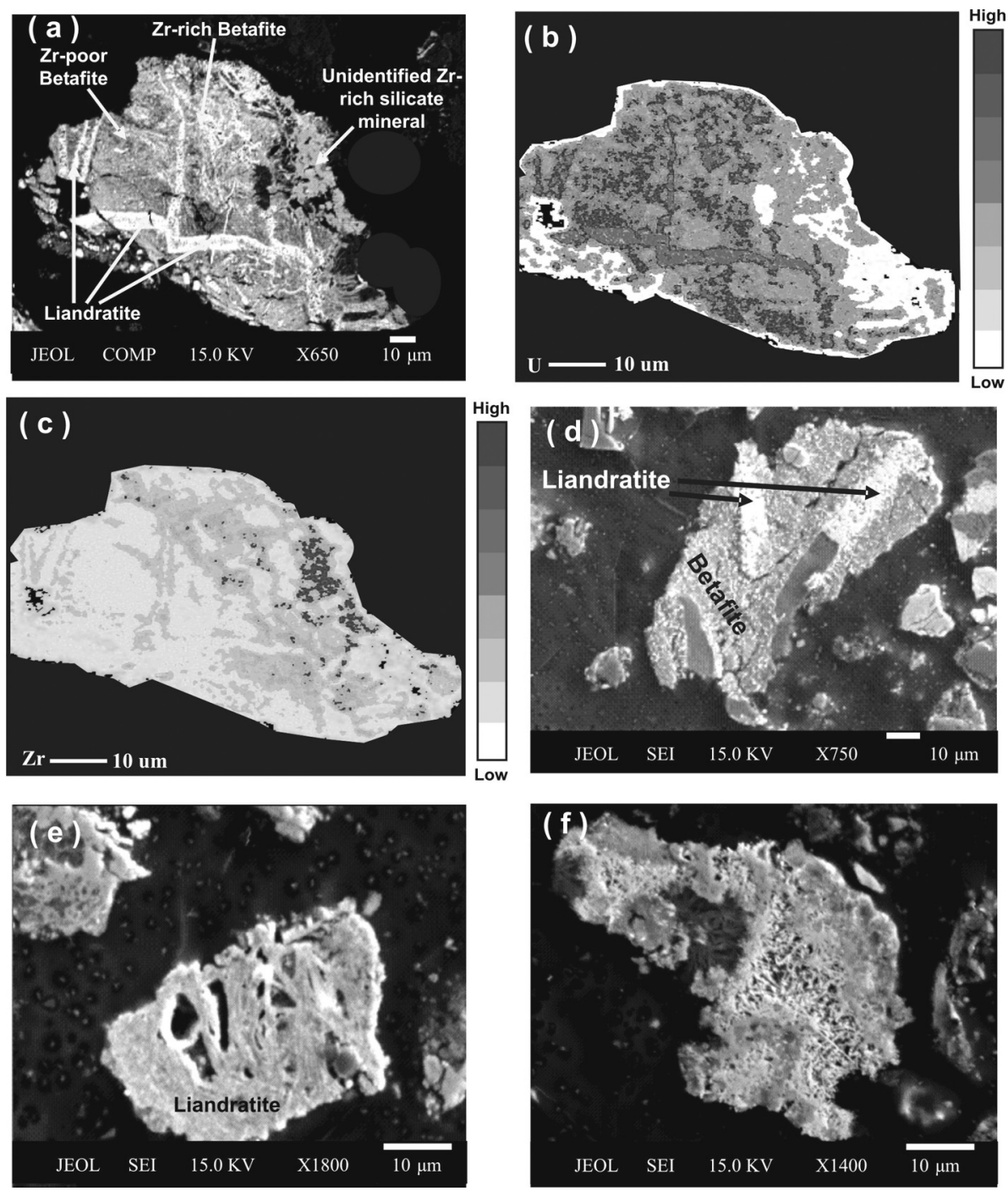

Figure 6. (a) BSE image showing the association of the unidentified Zr-rich silicate mineral, Zr-rich betafite, $\mathrm{Zr}$-poor betafite, and liandratite veins. (b) X-ray map showing the distribution of $U$ in the crystal of image (a). Liandratite shows the highest $\mathrm{U}$ value, followed by $\mathrm{Zr}^{-}$ poor betafite, and $\mathrm{Zr}$-rich betafite, whereas the unidentified $\mathrm{Zr}$-rich silicate mineral shows the lowest $\mathrm{U}$ value. (c) $\mathrm{X}$-ray map showing the distribution of $\mathrm{Zr}$ in the crystal of image (a). Liandratite shows the lowest $\mathrm{Zr}$ value, followed by $\mathrm{Zr}$ poor betafite, and $\mathrm{Zr}$-rich betafite, whereas the unidentified $\mathrm{Zr}$-rich silicate mineral shows the highest $\mathrm{Zr}$ value. (d) SEI image for liandratite as veins in betafite. (e), (f) SEI images for some liandratite crystals showing the dominant fibrous structure.

mineral has been identified by Williams et al. (2001). They interpreted it as being an alteration product of zirconolite, which occurs at Cummins Range, Sokli, Phalabora, and Sebl'yavr (Table 1). In these examples, zirconolite grains have been altered to form unidentified secondary $\mathrm{Zr}$-rich silicate minerals of variable composition, but which are all hydrated, enriched in $\mathrm{Ba}$ and $\mathrm{Si}$, and depleted in $\mathrm{Ca}$ and $\mathrm{Fe}$. These minerals are more abundant in $\mathrm{U}$ than in the precursor zirconolite, suggesting that these elements were mobilized and transported by magmatic-derived fluids enriched in $\mathrm{CO}_{2}, \mathrm{P}, \mathrm{F}, \mathrm{Na}$, and $\mathrm{K}$, and subsequently deposited with the alteration products (Williams et al., 2001). Figure 7a shows the REE distribution patterns in the unidentified $\mathrm{Zr}$-rich silicate mineral. These patterns are nearly flat with a clear negative $\mathrm{Nd}$ anomaly.

\section{Betafite}

The chemical composition of betafite strongly varies, and based on the following condition $2 \mathrm{Ti}>\mathrm{Nb}+\mathrm{Ta}$ and $\mathrm{UO}_{2}$ $>20 \%$ (Table 2), the mineral is placed in the betafite subgroup (Hogarth, 1977). The concentration of Ta is very low and is sometimes below the detection limit. It is found as separate grains or as rims around the unidentified Zr-rich silicate mineral (Fig. 5). X-ray maps show that the amount of $\mathrm{Zr}$ and $\mathrm{Si}$ in betafite is lower than that in the unidentified $\mathrm{Zr}$-rich silicate mineral; however, betafite is enriched in $\mathrm{U}, \mathrm{Ti}$, and $\mathrm{Nb}$ (Figs. 4 and 5). When compared to other $\mathrm{UO}_{2} \mathrm{wt} \%$ in stoichiometric non-metamict betafite reported in the mineralogical literature (average of $31.19 \mathrm{wt} \%$; Cámara et al., 2004), the studied betafite has a similar value (31.23 $\mathrm{wt} \% \mathrm{UO}_{2}$, Table 2$)$. The amount of $\mathrm{ZrO}_{2}$ ranges between 13.24 and $29.01 \mathrm{wt} \%$ with an average of $23.25 \mathrm{wt} \%$. However, some analyses 
Table 1. Selected electron microprobe data (in wt $\%$ ) of the unidentified secondary $\mathrm{Zr}$-rich silicate mineral in the trachyte of the El Atshan area

\begin{tabular}{|c|c|c|c|c|c|c|c|c|c|}
\hline Sample & 1 & 2 & 3 & 4 & 5 & 6 & 7 & 8 & Will.et al.* \\
\hline$\overline{\mathrm{SiO}_{2}}$ & 24.54 & 20.46 & 23.01 & 23.03 & 18.96 & 23.38 & 23.63 & 25.51 & 22.70 \\
\hline $\mathrm{Al}_{2} \mathrm{O}_{3}$ & 1.19 & 1.13 & 1.08 & 1.09 & 1.15 & 1.05 & 1.17 & 1.15 & $<0.05$ \\
\hline $\mathrm{TiO}_{2}$ & 2.61 & 3.50 & 3.25 & 3.08 & 2.13 & 0.72 & 0.71 & 2.65 & 10.00 \\
\hline $\mathrm{P}_{2} \mathrm{O}_{5}$ & 1.63 & 1.15 & 1.15 & 0.74 & 1.19 & 2.98 & 4.05 & 1.24 & 0.00 \\
\hline $\mathrm{Nb}_{2} \mathrm{O}_{5}$ & 2.08 & 1.90 & 1.37 & 1.15 & 2.77 & 2.14 & 2.44 & 1.73 & 3.27 \\
\hline $\mathrm{Ta}_{2} \mathrm{O}_{5}$ & 0.23 & b.d. $* * *$ & 0.23 & 0.01 & 0.20 & b.d. & 0.14 & b.d. & 0.46 \\
\hline $\mathrm{FeO}$ & 1.48 & 0.98 & 0.94 & 0.96 & 1.04 & 1.29 & 1.24 & 1.45 & 1.20 \\
\hline $\mathrm{ZrO}_{2}$ & 37.76 & 32.87 & 32.91 & 32.99 & 36.75 & 47.66 & 45.44 & 38.24 & 43.10 \\
\hline $\mathrm{HfO}_{2}$ & 0.58 & 0.44 & 0.70 & 0.73 & 0.29 & 0.53 & 0.82 & 0.47 & 1.05 \\
\hline $\mathrm{CaO}$ & 5.88 & 5.79 & 5.85 & 5.42 & 3.69 & 3.01 & 2.19 & 5.43 & 1.56 \\
\hline $\mathrm{UO}_{2}$ & 11.34 & 17.64 & 16.42 & 16.04 & 16.70 & 4.03 & 4.87 & 10.04 & 0.60 \\
\hline $\mathrm{ThO}_{2}$ & 0.04 & 0.18 & 0.12 & 0.10 & 0.11 & 0.03 & 0.01 & 0.16 & 1.36 \\
\hline $\mathrm{PbO}$ & 0.60 & 0.53 & 0.64 & 0.57 & 0.74 & 0.35 & 0.51 & 0.55 & $<0.1$ \\
\hline $\mathrm{Y}_{2} \mathrm{O}_{3}$ & 2.13 & 1.59 & 1.14 & 1.33 & 1.33 & 1.42 & 1.58 & 1.92 & \\
\hline $\mathrm{La}_{2} \mathrm{O}_{3}$ & 0.043 & 0.052 & 0.079 & 0.482 & 0.427 & 0.032 & 0.032 & 0.126 & \\
\hline $\mathrm{Ce}_{2} \mathrm{O}_{3}$ & 1.207 & 1.984 & 2.007 & 1.984 & 1.931 & 1.315 & 1.336 & 1.043 & \\
\hline $\mathrm{Pr}_{2} \mathrm{O}_{3}$ & 0.146 & 0.231 & 0.323 & 0.185 & 0.163 & 0.018 & 0.139 & 0.119 & \\
\hline $\mathrm{Nd}_{2} \mathrm{O}_{3}$ & 0.080 & 0.044 & 0.045 & 0.030 & 0.030 & 0.030 & 0.030 & 0.030 & \\
\hline $\mathrm{Sm}_{2} \mathrm{O}_{3}$ & 0.477 & 0.410 & 0.405 & 0.505 & 0.396 & 0.355 & 0.407 & 0.475 & \\
\hline $\mathrm{Gd}_{2} \mathrm{O}_{3}$ & 0.660 & 0.455 & 0.704 & 0.638 & 0.338 & 0.642 & 0.511 & 0.708 & 5.8 \\
\hline $\mathrm{Dy}_{2} \mathrm{O}_{3}$ & 1.041 & 0.428 & 0.497 & 0.517 & 0.479 & 0.637 & 0.704 & 0.824 & \\
\hline $\mathrm{Ho}_{2} \mathrm{O}_{3}$ & 0.298 & 0.159 & 0.214 & 0.105 & 0.286 & 0.209 & 0.274 & 0.334 & \\
\hline $\mathrm{Er}_{2} \mathrm{O}_{3}$ & 0.331 & 0.162 & 0.266 & 0.083 & 0.149 & 0.389 & 0.020 & 0.204 & \\
\hline $\mathrm{Tm}_{2} \mathrm{O}_{3}$ & 0.187 & 0.013 & 0.015 & 0.147 & 0.136 & 0.079 & 0.011 & 0.065 & \\
\hline $\mathrm{Yb}_{2} \mathrm{O}_{3}$ & 0.214 & 0.051 & 0.422 & 0.177 & 0.279 & 0.186 & 0.201 & 0.065 & \\
\hline $\mathrm{Lu}_{2} \mathrm{O}_{3}$ & 0.174 & 0.201 & 0.051 & 0.088 & 0.051 & 0.053 & 0.114 & 0.185 & $\longrightarrow$ \\
\hline Total & 96.95 & 92.34 & 93.84 & 92.17 & 91.72 & 92.53 & 92.59 & 94.70 & 91.10 ** \\
\hline$\Sigma \mathrm{RRE}+\mathrm{Y}$ & 6.99 & 6.78 & 6.17 & 6.27 & 5.99 & 5.36 & 5.36 & 6.10 & 5.80 \\
\hline $\mathrm{Ce} / \mathrm{Y}$ & 0.57 & 1.24 & 1.76 & 1.49 & 1.46 & 0.93 & 0.85 & 0.54 & 1.50 \\
\hline \multicolumn{10}{|c|}{ Structural formula based on $\mathrm{O}=7$} \\
\hline $\mathrm{Si}$ & 1.490 & 1.380 & 1.500 & 1.530 & 1.310 & 1.430 & 1.430 & 1.560 & 1.380 \\
\hline $\mathrm{Al}$ & 0.090 & 0.090 & 0.080 & 0.090 & 0.090 & 0.080 & 0.080 & 0.080 & 0.000 \\
\hline $\mathrm{Ti}$ & 0.120 & 0.180 & 0.160 & 0.150 & 0.110 & 0.030 & 0.030 & 0.120 & 0.460 \\
\hline $\mathrm{P}$ & 0.080 & 0.070 & 0.060 & 0.040 & 0.070 & 0.150 & 0.210 & 0.060 & 0.000 \\
\hline $\mathrm{Nb}$ & 0.060 & 0.060 & 0.040 & 0.030 & 0.090 & 0.060 & 0.070 & 0.050 & 0.090 \\
\hline Ta & 0.000 & 0.000 & 0.000 & 0.000 & 0.000 & 0.000 & 0.000 & 0.000 & 0.010 \\
\hline $\mathrm{Fe}$ & 0.080 & 0.060 & 0.050 & 0.050 & 0.060 & 0.070 & 0.060 & 0.070 & 0.060 \\
\hline $\mathrm{Zr}$ & 1.120 & 1.080 & 1.040 & 1.070 & 1.240 & 1.420 & 1.340 & 1.140 & 1.270 \\
\hline $\mathrm{Hf}$ & 0.010 & 0.010 & 0.010 & 0.010 & 0.010 & 0.010 & 0.010 & 0.010 & 0.020 \\
\hline $\mathrm{Ca}$ & 0.380 & 0.420 & 0.410 & 0.380 & 0.270 & 0.200 & 0.140 & 0.360 & 0.100 \\
\hline $\mathrm{U}$ & 0.150 & 0.270 & 0.240 & 0.240 & 0.260 & 0.050 & 0.070 & 0.140 & 0.010 \\
\hline Th & 0.000 & 0.000 & 0.000 & 0.000 & 0.000 & 0.000 & 0.000 & 0.000 & 0.020 \\
\hline $\mathrm{Pb}$ & 0.010 & 0.010 & 0.010 & 0.010 & 0.010 & 0.010 & 0.010 & 0.010 & 0.000 \\
\hline Y & 0.070 & 0.060 & 0.040 & 0.050 & 0.050 & 0.050 & 0.050 & 0.060 & \\
\hline $\mathrm{La}$ & 0.000 & 0.000 & 0.000 & 0.010 & 0.010 & 0.000 & 0.000 & 0.000 & \\
\hline $\mathrm{Ce}$ & 0.030 & 0.050 & 0.050 & 0.050 & 0.050 & 0.030 & 0.030 & 0.020 & \\
\hline $\operatorname{Pr}$ & 0.000 & 0.010 & 0.010 & 0.000 & 0.000 & 0.000 & 0.000 & 0.000 & \\
\hline $\begin{array}{l}\mathrm{Sm} \\
\mathrm{Gd}\end{array}$ & 0.010 & 0.010 & 0.010 & 0.010 & 0.010 & 0.010 & 0.010 & 0.010 & 0.19 \\
\hline $\begin{array}{l}\text { Gd } \\
\text { Dy }\end{array}$ & 0.010 & 0.010 & 0.020 & 0.010 & 0.010 & 0.010 & 0.010 & 0.010 & \\
\hline $\begin{array}{l}\text { Dy } \\
\text { Ho }\end{array}$ & $\begin{array}{l}0.020 \\
0.010\end{array}$ & $\begin{array}{l}0.010 \\
0.000\end{array}$ & 0.010 & 0.010 & 0.010 & 0.010 & 0.010 & 0.020 & \\
\hline $\mathrm{Er}$ & 0.010 & 0.000 & 0.010 & 0.000 & 0.000 & 0.010 & 0.000 & 0.000 & \\
\hline $\mathrm{Yb}$ & 0.000 & 0.000 & 0.010 & 0.000 & 0.010 & 0.000 & 0.000 & 0.000 & \\
\hline Total & 3.75 & 3.78 & 3.76 & 3.74 & 3.68 & 3.63 & 3.57 & 3.73 & $3 . \overline{61}$ \\
\hline
\end{tabular}

${ }^{*}$ Microprobe analysis of the unidentified secondary Zr-rich silicate mineral as an alteration product of zirconolite from Cummins Range, Australia (Williams et al., 2001).

** Includes $\mathrm{MgO}, 0.25 ; \mathrm{MnO}, 0.05 \mathrm{wt} \%$.

**** b.d., below detection limit $\left(\mathrm{ThO}_{2}, 0.01 ; \mathrm{La}_{2} \mathrm{O}_{3}, 0.02 ; \mathrm{Pr}_{2} \mathrm{O}_{3}, 0.026 ; \mathrm{Nd}_{2} \mathrm{O}_{3}, 0.01 ; \mathrm{Sm}_{2} \mathrm{O}_{3}, 0.028 ; \mathrm{Gd}_{2} \mathrm{O}_{3}, 0.042 ; \mathrm{Dy}_{2} \mathrm{O}_{3}, 0.01 ; \mathrm{Ho}_{2} \mathrm{O}_{3}, 0.01\right.$; $\mathrm{Er}_{2} \mathrm{O}_{3}, 0.005 ; \mathrm{Tm}_{2} \mathrm{O}_{3}, 0.006 ; \mathrm{Yb}_{2} \mathrm{O}_{3}, 0.009 ; \mathrm{Lu}_{2} \mathrm{O}_{3}, 0.018 ; \mathrm{Ta}_{2} \mathrm{O}_{5}, 0.01 ; \mathrm{HfO}_{2}, 0.009$ wt $\%$ ). 


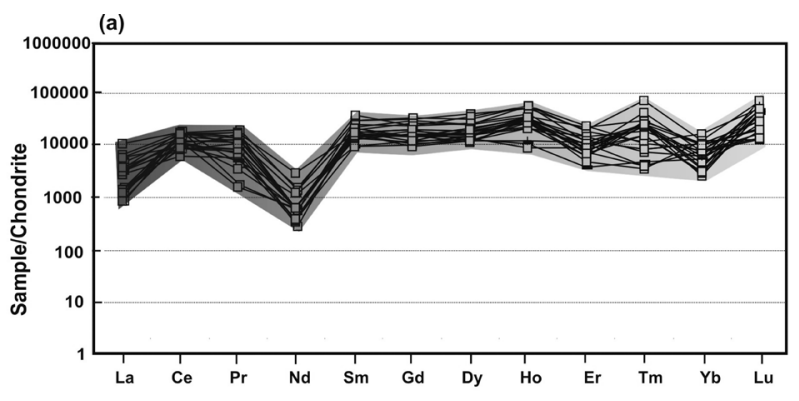

(b)

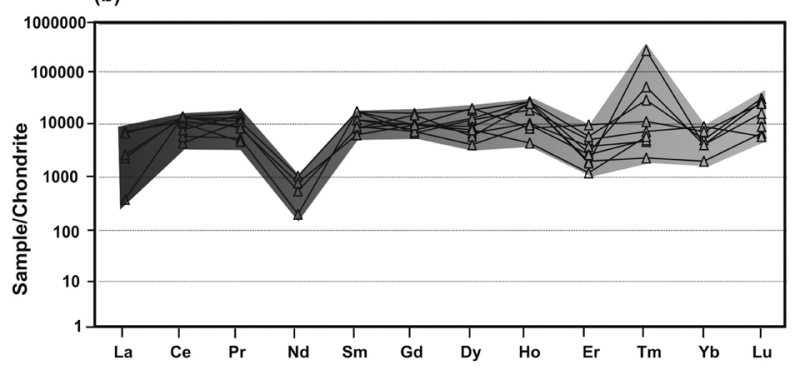

(c)

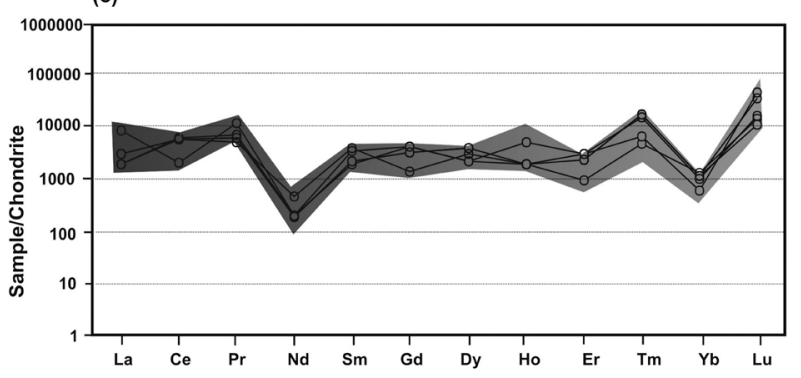

Figure 7. Chondrite-normalized REE patterns of (a) the unidentified $\mathrm{Zr}$-rich silicate mineral, (b) betafite, and (c) liandratite. The REE normalization is based on the chondrite data provided by Anders and Grevesse (1989).

show lower values for the $\mathrm{Zr}$ content $(\sim 6 \mathrm{wt} \%)$. The incorporation of $\mathrm{Zr}^{4+}$, an ion of intermediate size, is wellknown in natural pyrochlore, where $\mathrm{Zr}^{4+}$ is assigned to the $B$-site in accordance with the synthetic REE-Zr pyrochlore (Hayakawa and Kamizono, 1993; Subramanian et al., 1983).

The formula of betafite was calculated by assuming $2.00 B$-site cations per formula unit (Table 2), assuming that $\mathrm{Al}, \mathrm{P}, \mathrm{V}$, and $\mathrm{Zr}$ occupy the $B$-site and all $\mathrm{Fe}$ is present as $\mathrm{Fe}^{3+}$ at the $B$-site. Si may occupy either the $A^{-}$or the $B$-site because both these sites are octahedrally coordinated. Si was chosen to be placed in the $B$-site because it seems unlikely that small cations such as $\mathrm{Si}$ share the same site as large cations such as $\mathrm{Pb}, \mathrm{Na}$, and $\mathrm{Ca}$. Placing $\mathrm{Si}$ in the $B$-site has been also documented by Subramanian et al. (1983) and Johan and Johan (1994). The obtained chemical formula is ${ }^{A}\left(\mathrm{U}_{0.44} \mathrm{Ca}_{0.25} \mathrm{REE}_{0.05} \mathrm{Y}_{0.03} \mathrm{~Pb}_{0.02}\right)_{\Sigma 0.79}{ }^{B}\left(\mathrm{Si}_{0.79}\right.$ $\left.\mathrm{Zr}_{0.69} \mathrm{Ti}_{0.23} \mathrm{Nb}_{0.12} \mathrm{Al}_{0.06} \mathrm{Fe}_{0.05} \mathrm{P}_{0.03} \mathrm{~V}_{0.02} \mathrm{Hf}_{0.01}\right)_{\Sigma 2.0} \mathrm{O}_{7}$.

The total amount of REE in betafite is relatively lower than that measured in the unidentified $\mathrm{Zr}$-rich silicate mineral (average $\Sigma \mathrm{REE}=2.70 \mathrm{wt} \%$ ). In general, one can observe that the REE pattern of betafite (Fig. 7b) and the unidentified secondary Zr-rich silicate mineral (Fig. 7a) are quite similar and show negative Nd anomaly. Similarity in the plots of REE data in these minerals suggests that the alteration process did not cause marked fractionation of the REEs during the alteration of the unidentified Zr-rich silicate mineral to betafite.

\section{Liandratite}

Liandratite is yellow in color and has a higher BSE intensity than betafite and the unidentified $\mathrm{Zr}$-rich silicate mineral (Fig. 6a). It is found as a vein in betafite (Figs. 6a6d), as a rim around betafite, or as separate grains (Figs. 6e and 6f). When compared to the unidentified $\mathrm{Zr}$-rich silicate mineral and betafite, liandratite has the highest uranium content and lowest zirconium content. It has REE patterns that are similar to the patterns of the unidentified $\mathrm{Zr}$-rich silicate mineral and betafite with $\mathrm{Nd}$ anomaly (Fig. 7c). The formula unit of liandratite is normalized by assuming $2.00 \mathrm{Nb}$-site cations per formula unit (Table 3 ), with similar assumptions that made for betafite concerning the amount of $\mathrm{Zr}, \mathrm{Si}, \mathrm{Fe}, \mathrm{P}$, and $\mathrm{Al}$ in the $\mathrm{Nb}$-site. The calculated formula is ${ }^{U}\left(\mathrm{U}_{1.35} \mathrm{Ca}_{0.41} \mathrm{~Pb}_{0.04} \mathrm{REE}_{0.04} \mathrm{Y}_{0.01}\right)_{\Sigma 1.86}$ ${ }^{N b}\left(\mathrm{Ti}_{0.67} \mathrm{Si}_{0.46} \mathrm{Nb}_{0.40} \mathrm{Zr}_{0.26} \mathrm{Fe}_{0.09} \mathrm{~V}_{0.08} \mathrm{Al}_{0.03} \mathrm{Ta}_{0.01}\right)_{\Sigma 2.0} \mathrm{O}_{8}$, where $\mathrm{U}, \mathrm{Ca}, \mathrm{Ti}$, and $\mathrm{Nb}$ represent the principle elements with considerable amounts of $\mathrm{Si}, \mathrm{Zr}$, and traces of $\mathrm{Fe}, \mathrm{Pb}, \mathrm{V}$, $\mathrm{Al}, \mathrm{Ta}, \mathrm{P}$, and REEs.

The composition of liandratite in Madagascar (Lumpkin and Ewing, 1996) is similar to that of the studied liandratite, especially in major constituents such as $\mathrm{U}$ and $\mathrm{Nb}$ (Table 3). The calculated chemical formula is similar to the theoretical formula of liandratite $\left(\mathrm{U}^{6+} \square\right.$ $\mathrm{Nb}_{2} \mathrm{O}_{8}$ ) (Mücke and Strunz, 1978; Lumpkin and Ewing, 1996). The average of $U$-site total (1.86 atoms) is in agreement with the normal values (maximum 2). In addition, the ratio of $U: N b$-sites appears closer to $2: 2$ of liandratite.

\section{DISCUSSION}

The formation of the trachyte sill at the El Atshan area is related to the tensional tectonic event that produced big fissures connecting the mantle material with the upper crust. This tectonic event is probably related to the late Pan-African tectono-thermal event that involves PermoTriassic magmatism, the Late Jurassic-Early Cretaceous hydrothermal phase, Late Cretaceous-Early Tertiary hydrothermal phase, and the Tertiary volcanicity and OligoMiocene phase (Dawood et al., 2004). The occurrence of 
Table 2. Selected electron microprobe data (in wt $\%$ ) of betafite in the trachyte of the El Atshan area

\begin{tabular}{|c|c|c|c|c|c|c|c|c|}
\hline Sample & 1 & 2 & 3 & 4 & 5 & 6 & 7 & 8 \\
\hline $\mathrm{UO}_{2}$ & 26.59 & 27.50 & 28.02 & 29.49 & 24.26 & 30.17 & 35.60 & 31.46 \\
\hline $\mathrm{CaO}$ & 4.85 & 3.68 & 3.97 & 4.11 & 4.27 & 3.40 & 3.29 & 3.46 \\
\hline $\mathrm{ThO}_{2}$ & 0.05 & 0.14 & b.d. & b.d. & b.d. & b.d. & b.d. & b.d. \\
\hline $\mathrm{PbO}$ & 0.77 & 0.90 & 0.84 & 1.10 & 0.90 & 1.12 & 1.21 & 1.03 \\
\hline $\mathrm{Y}_{2} \mathrm{O}_{3}$ & 0.56 & 0.67 & 1.35 & 0.80 & 1.04 & 1.05 & 0.86 & 0.98 \\
\hline $\mathrm{La}_{2} \mathrm{O}_{3}$ & b.d. & 0.24 & b.d. & b.d. & b.d. & 0.09 & 0.27 & 0.02 \\
\hline $\mathrm{Ce}_{2} \mathrm{O}_{3}$ & 0.44 & 0.50 & 0.61 & 0.81 & 1.09 & 1.37 & 1.11 & 1.38 \\
\hline $\mathrm{Pr}_{2} \mathrm{O}_{3}$ & 0.15 & b.d. & 0.08 & 0.22 & 0.07 & 0.22 & 0.13 & 0.12 \\
\hline $\mathrm{Nd}_{2} \mathrm{O}_{3}$ & 0.08 & 0.08 & 0.02 & b.d. & b.d. & b.d. & 0.04 & 0.06 \\
\hline $\mathrm{Sm}_{2} \mathrm{O}_{3}$ & 0.39 & 0.34 & 0.41 & 0.27 & 0.40 & 0.28 & 0.20 & 0.15 \\
\hline $\mathrm{Gd}_{2} \mathrm{O}_{3}$ & 0.21 & 0.02 & 0.50 & 0.24 & 0.30 & 0.29 & 0.31 & 0.30 \\
\hline $\mathrm{Dy}_{2} \mathrm{O}_{3}$ & 0.45 & 0.35 & 0.69 & 0.50 & 0.77 & 0.35 & 0.26 & 0.31 \\
\hline $\mathrm{Ho}_{2} \mathrm{O}_{3}$ & 0.16 & 0.22 & 0.24 & 0.23 & 0.07 & 0.22 & 0.09 & 0.04 \\
\hline $\mathrm{Er}_{2} \mathrm{O}_{3}$ & 0.13 & 0.07 & 0.15 & 0.07 & 0.25 & 0.05 & 0.09 & 0.03 \\
\hline $\mathrm{Tm}_{2} \mathrm{O}_{3}$ & 0.03 & 0.03 & 0.11 & 0.19 & 0.04 & 0.01 & 0.02 & 0.02 \\
\hline $\mathrm{Yb}_{2} \mathrm{O}_{3}$ & 0.22 & b.d. & 0.13 & 0.11 & 0.18 & 0.05 & b.d. & b.d. \\
\hline $\mathrm{Lu}_{2} \mathrm{O}_{3}$ & 0.02 & 0.22 & 0.11 & 0.10 & 0.09 & 0.03 & 0.05 & 0.02 \\
\hline $\mathrm{SiO}_{2}$ & 13.45 & 15.21 & 15.39 & 13.21 & 15.86 & 13.79 & 12.46 & 13.21 \\
\hline $\mathrm{Al}_{2} \mathrm{O}_{3}$ & 0.95 & 0.76 & 0.84 & 0.70 & 1.03 & 0.95 & 0.73 & 0.79 \\
\hline $\mathrm{TiO}_{2}$ & 4.79 & 4.50 & 3.60 & 4.13 & 3.21 & 4.24 & 5.14 & 4.74 \\
\hline $\mathrm{P}_{2} \mathrm{O}_{5}$ & 3.65 & 0.82 & 0.71 & 0.09 & 0.52 & 0.46 & 0.39 & 0.30 \\
\hline $\mathrm{Nb}_{2} \mathrm{O}_{5}$ & 4.39 & 3.77 & 3.52 & 4.36 & 3.09 & 4.21 & 4.82 & 4.22 \\
\hline $\mathrm{Ta}_{2} \mathrm{O}_{5}$ & 0.25 & 0.25 & 0.08 & 0.15 & b.d. & 0.02 & 0.27 & 0.22 \\
\hline $\mathrm{FeO}$ & 1.41 & 0.99 & 1.12 & 0.94 & 0.89 & 0.90 & 0.91 & 0.91 \\
\hline $\mathrm{ZrO}_{2}$ & 22.06 & 29.01 & 26.19 & 22.20 & 29.66 & 26.41 & 22.53 & 25.84 \\
\hline $\mathrm{HfO}_{2}$ & 0.30 & 0.58 & 0.32 & 0.49 & 0.45 & 0.34 & 0.24 & 0.35 \\
\hline $\mathrm{V}_{2} \mathrm{O}_{3}$ & 0.47 & 0.54 & 0.51 & 0.30 & 0.17 & 0.39 & 0.48 & 0.39 \\
\hline Total & 86.804 & 91.391 & 89.498 & 84.781 & 88.611 & 90.393 & 91.488 & 90.354 \\
\hline \multicolumn{9}{|c|}{ Structural formula based on $\Sigma B=2$} \\
\hline $\mathrm{Ca}$ & 0.290 & 0.210 & 0.240 & 0.280 & 0.250 & 0.210 & 0.220 & 0.220 \\
\hline $\mathrm{U}$ & 0.330 & 0.330 & 0.350 & 0.420 & 0.290 & 0.390 & 0.500 & 0.410 \\
\hline Th & 0.000 & 0.000 & 0.000 & 0.000 & 0.000 & 0.000 & 0.000 & 0.000 \\
\hline $\mathrm{Pb}$ & 0.010 & 0.010 & 0.010 & 0.020 & 0.010 & 0.020 & 0.020 & 0.020 \\
\hline Y & 0.020 & 0.020 & 0.040 & 0.030 & 0.030 & 0.030 & 0.030 & 0.030 \\
\hline $\mathrm{La}$ & 0.000 & 0.000 & 0.000 & 0.000 & 0.000 & 0.000 & 0.010 & 0.000 \\
\hline $\mathrm{Ce}$ & 0.010 & 0.010 & 0.010 & 0.020 & 0.020 & 0.030 & 0.030 & 0.030 \\
\hline $\mathrm{Pr}$ & 0.000 & 0.000 & 0.000 & 0.000 & 0.000 & 0.000 & 0.000 & 0.000 \\
\hline $\mathrm{Nd}$ & 0.000 & 0.000 & 0.000 & 0.000 & 0.000 & 0.000 & 0.000 & 0.000 \\
\hline $\mathrm{Sm}$ & 0.010 & 0.010 & 0.010 & 0.010 & 0.010 & 0.010 & 0.000 & 0.000 \\
\hline $\mathrm{Gd}$ & 0.000 & 0.000 & 0.010 & 0.010 & 0.010 & 0.010 & 0.010 & 0.010 \\
\hline Dy & 0.010 & 0.010 & 0.010 & 0.010 & 0.010 & 0.010 & 0.010 & 0.010 \\
\hline Ho & 0.000 & 0.000 & 0.000 & 0.000 & 0.000 & 0.000 & 0.000 & 0.000 \\
\hline Er & 0.000 & 0.000 & 0.000 & 0.000 & 0.000 & 0.000 & 0.000 & 0.000 \\
\hline $\mathrm{Tm}$ & 0.000 & 0.000 & 0.000 & 0.000 & 0.000 & 0.000 & 0.000 & 0.000 \\
\hline $\mathrm{Yb}$ & 0.000 & 0.000 & 0.000 & 0.000 & 0.000 & 0.000 & 0.000 & 0.000 \\
\hline $\mathrm{Lu}$ & 0.000 & 0.000 & 0.000 & 0.000 & 0.000 & 0.000 & 0.000 & 0.000 \\
\hline$\Sigma A$ & 0.680 & 0.600 & 0.680 & 0.800 & 0.630 & 0.710 & 0.830 & 0.730 \\
\hline $\mathrm{Si}$ & 0.750 & 0.810 & 0.870 & 0.840 & 0.860 & 0.800 & 0.780 & 0.780 \\
\hline $\mathrm{Al}$ & 0.060 & 0.050 & 0.060 & 0.050 & 0.070 & 0.060 & 0.050 & 0.060 \\
\hline $\mathrm{Ti}$ & 0.200 & 0.180 & 0.150 & 0.200 & 0.130 & 0.180 & 0.240 & 0.210 \\
\hline $\mathrm{P}$ & 0.170 & 0.040 & 0.030 & 0.000 & 0.020 & 0.020 & 0.020 & 0.020 \\
\hline $\mathrm{Nb}$ & 0.110 & 0.090 & 0.090 & 0.130 & 0.080 & 0.110 & 0.140 & 0.110 \\
\hline $\mathrm{Ta}$ & 0.000 & 0.000 & 0.000 & 0.000 & 0.000 & 0.000 & 0.000 & 0.000 \\
\hline $\mathrm{Zr}$ & 0.600 & 0.750 & 0.720 & 0.690 & 0.790 & 0.750 & 0.690 & 0.740 \\
\hline $\mathrm{Hf}$ & 0.000 & 0.010 & 0.010 & 0.010 & 0.010 & 0.010 & 0.000 & 0.010 \\
\hline $\mathrm{Fe}$ & 0.070 & 0.040 & 0.050 & 0.050 & 0.040 & 0.040 & 0.050 & 0.040 \\
\hline V & 0.020 & 0.020 & 0.020 & 0.020 & 0.010 & 0.020 & 0.020 & 0.020 \\
\hline$\Sigma B$ & 1.980 & 1.990 & 2.000 & 1.990 & 2.010 & 1.990 & 1.990 & 1.990 \\
\hline$\Sigma A+B$ & 2.660 & 2.590 & 2.680 & 2.790 & 2.640 & 2.700 & 2.820 & 2.720 \\
\hline
\end{tabular}


Table 3. Selected electron microprobe data (in wt $\%$ ) of liandratite in the trachyte of the El Atshan area

\begin{tabular}{|c|c|c|c|c|c|c|c|c|}
\hline Sample & 1 & 2 & 3 & 4 & 5 & 6 & 7 & L \& E* \\
\hline $\mathrm{UO}_{3}$ & 60.39 & 56.14 & 53.24 & 57.10 & 56.05 & 55.20 & 55.92 & 54.87 \\
\hline $\mathrm{CaO}$ & 3.44 & 3.51 & 4.04 & 3.39 & 3.46 & 3.79 & 3.33 & 0.26 \\
\hline $\mathrm{ThO}_{2}$ & 0.01 & b.d. & b.d. & b.d. & b.d. & b.d. & b.d. & 1.19 \\
\hline $\mathrm{PbO}$ & 2.00 & 1.17 & 1.34 & 1.43 & 1.34 & 1.26 & 1.00 & 2.10 \\
\hline $\mathrm{Y}_{2} \mathrm{O}_{3}$ & b.d. & 0.16 & 0.10 & 0.19 & 0.20 & 0.28 & 0.27 & 0.18 \\
\hline $\mathrm{La}_{2} \mathrm{O}_{3}$ & 0.47 & 0.09 & 0.18 & b.d. & 0.09 & 0.04 & 0.16 & \multirow{12}{*}{0.87} \\
\hline $\mathrm{Ce}_{2} \mathrm{O}_{3}$ & 0.26 & 0.87 & 0.04 & 0.99 & 0.84 & 0.94 & 0.82 & \\
\hline $\mathrm{Pr}_{2} \mathrm{O}_{3}$ & 0.25 & b.d. & 0.11 & 0.17 & 0.10 & 0.15 & 0.13 & \\
\hline $\mathrm{Nd}_{2} \mathrm{O}_{3}$ & b.d. & 0.02 & 0.07 & 0.09 & 0.04 & b.d. & 0.01 & \\
\hline $\mathrm{Sm}_{2} \mathrm{O}_{3}$ & 0.06 & 0.11 & 0.16 & b.d. & 0.12 & 0.11 & 0.07 & \\
\hline $\mathrm{Gd}_{2} \mathrm{O}_{3}$ & b.d. & 0.18 & 0.08 & b.d. & b.d. & 0.24 & 0.14 & \\
\hline $\mathrm{Dy}_{2} \mathrm{O}_{3}$ & b.d. & 0.11 & b.d. & 0.16 & 0.16 & 0.07 & 0.21 & \\
\hline $\mathrm{Ho}_{2} \mathrm{O}_{3}$ & b.d. & b.d. & 0.01 & 0.10 & 0.02 & 0.09 & 0.00 & \\
\hline $\mathrm{Er}_{2} \mathrm{O}_{3}$ & 0.03 & 0.10 & b.d. & b.d. & 0.10 & 0.07 & 0.07 & \\
\hline $\mathrm{Tm}_{2} \mathrm{O}_{3}$ & 0.03 & b.d. & 0.10 & b.d. & 0.09 & 0.00 & 0.10 & \\
\hline $\mathrm{Yb}_{2} \mathrm{O}_{3}$ & 0.04 & b.d. & 0.31 & 0.13 & b.d. & b.d. & 0.04 & \\
\hline $\mathrm{Lu}_{2} \mathrm{O}_{3}$ & 0.08 & 0.31 & b.d. & 0.07 & 0.10 & 0.07 & b.d. & \\
\hline $\mathrm{SiO}_{2}$ & 3.34 & 4.07 & 3.41 & 3.79 & 4.80 & 4.85 & 6.17 & 0.00 \\
\hline $\mathrm{Al}_{2} \mathrm{O}_{3}$ & 0.12 & 0.20 & 0.20 & 0.24 & 0.27 & 0.37 & 0.55 & 0.79 \\
\hline $\mathrm{TiO}_{2}$ & 9.45 & 7.85 & 9.28 & 8.28 & 7.40 & 8.03 & 7.21 & 6.48 \\
\hline $\mathrm{Nb}_{2} \mathrm{O}_{5}$ & 10.17 & 7.82 & 6.82 & 8.89 & 8.28 & 8.11 & 6.92 & 25.20 \\
\hline $\mathrm{Ta}_{2} \mathrm{O}_{5}$ & b.d. & 0.20 & 0.39 & 0.43 & 0.20 & 0.15 & 0.39 & 2.37 \\
\hline $\mathrm{Fe}_{2} \mathrm{O}_{3}$ & 1.23 & 0.92 & 0.89 & 0.97 & 0.97 & 1.04 & 0.97 & 1.56 \\
\hline $\mathrm{ZrO}_{2}$ & 1.89 & 4.25 & 4.11 & 4.40 & 6.72 & 7.16 & 6.19 & 0.10 \\
\hline $\mathrm{HfO}_{2}$ & b.d. & 0.03 & 0.05 & 0.13 & 0.13 & b.d. & 0.04 & \\
\hline $\mathrm{V}_{2} \mathrm{O}_{3}$ & 1.37 & 0.76 & 1.07 & 0.95 & 0.81 & 0.86 & 0.75 & \\
\hline Total & 94.62 & 88.84 & 85.99 & 91.88 & 92.31 & 92.87 & 91.45 & $98.04 * *$ \\
\hline \multicolumn{9}{|c|}{ Structural formula based on $\Sigma N b=2$} \\
\hline $\mathrm{U}$ & 1.480 & 1.450 & 1.360 & 1.400 & 1.300 & 1.220 & 1.250 & 1.270 \\
\hline $\mathrm{Ca}$ & 0.410 & 0.440 & 0.500 & 0.400 & 0.390 & 0.400 & 0.360 & 0.030 \\
\hline Th & 0.000 & 0.000 & 0.000 & 0.000 & 0.000 & 0.000 & 0.000 & 0.030 \\
\hline $\mathrm{Pb}$ & 0.060 & 0.040 & 0.040 & 0.040 & 0.040 & 0.030 & 0.030 & 0.060 \\
\hline Y & 0.000 & 0.010 & 0.010 & 0.010 & 0.010 & 0.010 & 0.010 & 0.010 \\
\hline $\mathrm{La}$ & 0.020 & 0.000 & 0.010 & 0.000 & 0.000 & 0.000 & 0.010 & \multirow{12}{*}{0.03} \\
\hline $\mathrm{Ce}$ & 0.010 & 0.040 & 0.000 & 0.040 & 0.030 & 0.030 & 0.030 & \\
\hline $\operatorname{Pr}$ & 0.010 & 0.000 & 0.000 & 0.010 & 0.000 & 0.010 & 0.000 & \\
\hline $\mathrm{Nd}$ & 0.000 & 0.000 & 0.000 & 0.000 & 0.000 & 0.000 & 0.000 & \\
\hline $\mathrm{Sm}$ & 0.000 & 0.000 & 0.010 & 0.000 & 0.000 & 0.000 & 0.000 & \\
\hline $\mathrm{Gd}$ & 0.000 & 0.010 & 0.000 & 0.000 & 0.000 & 0.010 & 0.000 & \\
\hline Dy & 0.000 & 0.000 & 0.000 & 0.010 & 0.010 & 0.000 & 0.010 & \\
\hline Ho & 0.000 & 0.000 & 0.000 & 0.000 & 0.000 & 0.000 & 0.000 & \\
\hline $\mathrm{Er}$ & 0.000 & 0.000 & 0.000 & 0.000 & 0.000 & 0.000 & 0.000 & \\
\hline $\mathrm{Tm}$ & 0.000 & 0.000 & 0.000 & 0.000 & 0.000 & 0.000 & 0.000 & \\
\hline $\mathrm{Yb}$ & 0.000 & 0.000 & 0.010 & 0.000 & 0.000 & 0.000 & 0.000 & \\
\hline $\mathrm{Lu}$ & 0.000 & 0.010 & 0.000 & 0.000 & 0.000 & 0.000 & 0.000 & \\
\hline$\Sigma U$ & 1.990 & 2.000 & 1.940 & 1.910 & 1.780 & 1.710 & 1.700 & $1.58 * * *$ \\
\hline $\mathrm{Si}$ & 0.370 & 0.470 & 0.390 & 0.420 & 0.500 & 0.480 & 0.620 & 0.000 \\
\hline $\mathrm{Al}$ & 0.020 & 0.030 & 0.030 & 0.030 & 0.030 & 0.040 & 0.060 & 0.100 \\
\hline $\mathrm{Ti}$ & 0.780 & 0.690 & 0.800 & 0.680 & 0.580 & 0.600 & 0.540 & 0.510 \\
\hline $\mathrm{Nb}$ & 0.510 & 0.410 & 0.350 & 0.440 & 0.390 & 0.360 & 0.310 & 1.190 \\
\hline $\mathrm{Ta}$ & 0.000 & 0.010 & 0.010 & 0.010 & 0.010 & 0.000 & 0.010 & 0.070 \\
\hline $\mathrm{Fe}$ & 0.110 & 0.090 & 0.090 & 0.090 & 0.080 & 0.090 & 0.080 & 0.140 \\
\hline $\mathrm{Zr}$ & 0.100 & 0.240 & 0.230 & 0.240 & 0.340 & 0.350 & 0.300 & 0.010 \\
\hline Hf & 0.000 & 0.000 & 0.000 & 0.000 & 0.000 & 0.000 & 0.000 & \\
\hline V & 0.120 & 0.070 & 0.100 & 0.080 & 0.070 & 0.070 & 0.060 & \\
\hline$\Sigma N b$ & 2.010 & 2.010 & 2.000 & 1.990 & 2.000 & 1.990 & 1.980 & 2.020 \\
\hline$\Sigma U+N b$ & 4.000 & 4.010 & 3.940 & 3.900 & 3.780 & 3.700 & 3.680 & 3.600 \\
\hline
\end{tabular}

${ }^{*}$ Microprobe analysis of liandratite as an alteration product of betafite from Madagascar (Lumpkin and Ewing, 1996)

*** Includes $\mathrm{MnO}, 0.14 ; \mathrm{BaO}, 0.89 ; \mathrm{K}_{2} \mathrm{O}, 0.70 ; \mathrm{Na}_{2} \mathrm{O}, 0.05 ; \mathrm{MgO}, 0.02 ; \mathrm{F}, 0.27 \mathrm{wt} \%$.

*** Includes $\mathrm{Mn}, 0.01 ; \mathrm{Ba}, 0.04 ; \mathrm{K}, 0.09 ; \mathrm{Na}, 0.01 ; \mathrm{Mg}, 0.00$. 


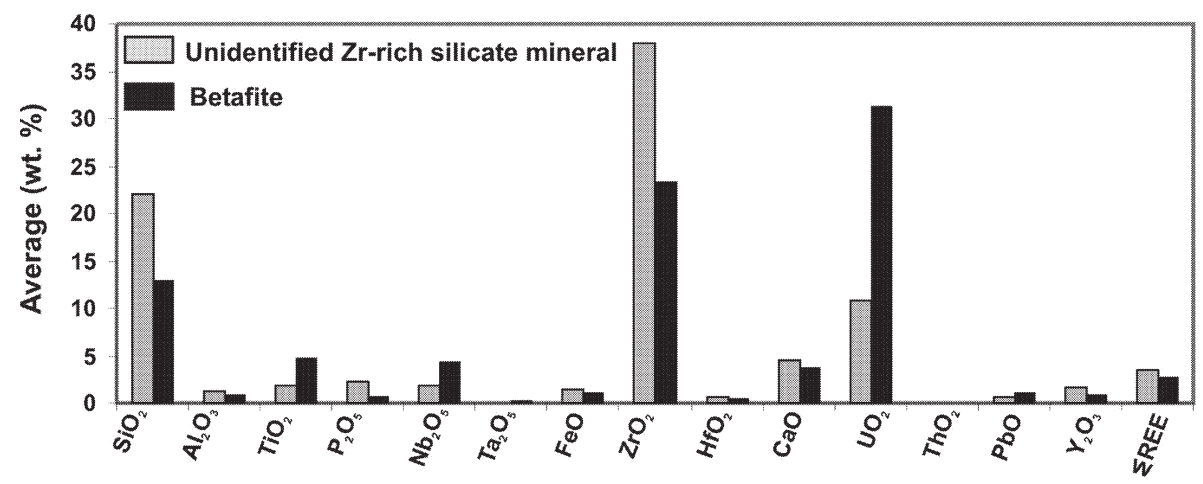

Figure 8. Histograms showing a comparison between the chemical composition of the unidentified $\mathrm{Zr}$-rich silicate mineral and betafite. this event in the Eastern Desert of Egypt is confirmed by paleomagnetic and radiometric data (Ressetar et al., 1981). This is consistent with the $273 \pm 20$ Ma age of the trachyte found in the El Atshan area (Late Carboniferous to Early Permian, El Manharawy, 1972). El Hazek (1968) studied the mineralogical, geochemical, and physical characteristics of the primary ore at the El Atshan area. He identified two primary uranium minerals - coffinite and pitchblende - and reported the occurrence of carbonates, quartz, and fluorite as gangue minerals. On the other hand, the secondary uranium minerals were found impregnating the fractured trachyte rock at the contact lines, occupying cavities and vugs, and occurred as stains on fracture surfaces. They are usually bright yellow in color, but they may be darker when mixed with reddishbrown iron oxides and black manganese oxides. The most important varieties are soddyite, kasolite, and uranophane (Attawiya, 1971; Osmond et al., 1999; Dawood et al., 2004). In addition, the unidentified secondary Zr-rich silicate mineral, betafite, and liandratite have been identified for the first time in the present study.

\section{Early high-temperature alteration stage}

After the formation of the trachyte sill at the El Atshan area, it was subjected to early-stage hydrothermal alteration that included argillization, dissolution of iron-bearing sulphides, formation of iron-oxy hydroxides, and corrosion of primary uranium minerals (Dawood et al., 2004). The hydrothermal solutions follow the main structural lines, including fault lines and the open fractures at both the upper and lower contacts of the trachyte sill with the surrounding Hammamat sediments. While flowing, the hydrothermal solutions may have leached uranium occurring in primary minerals such as coffinite and pitchblende from the host rock, and finally became enriched in $U$. Changing fluid chemistry, decreasing temperature, and the presence of volatiles (particularly F), played a key role in the transport and distribution of $U$ in the rocks during the hydrothermal alteration. The activity of fluoride in the present study is significant, as indicated from the occurrence of fluorite in association with $\mathrm{U}$-bearing minerals. The mobility of $U$ and the associated high-field strength elements (HFSE, i.e., Zr, Hf, Nb, and Ti) during fluid/rock interaction has been discussed by many authors (e.g., Chan et al., 1986; Rubin et al., 1993).

The extensive chemical variation in natural zirconolites and their synthetic equivalents has been reported in many publications where thirty or more elements may be accommodated at concentration levels ranging from 0.1 to $1.0 \mathrm{wt} \%$ (Williams and Gieré, 1996; Gieré et al., 1998). Zirconolite has the ideal formula $\mathrm{CaZrTi}_{2} \mathrm{O}_{7}$, in which the available cationic sites have 8 -coordination ( $\mathrm{Ca}$-site or M8 site) and 7-coordination ( $\mathrm{Zr}$-site or M7 site) and $\mathrm{Ti}$ in three distinct sites have 6-coordination ( $\mathrm{Ti}^{-}$-site or M6 site) and a pair of 5-coordination (M5 sites) (Gieré et al., 1998). When compared to other stoichiometrically ideal zirconolite mineral reported in the mineralogical literature (varies from 2.63 to $16.5 \mathrm{wt} \% \mathrm{CaO}$, from 24.3 to 45.4 $\mathrm{wt} \% \mathrm{ZrO}_{2}$, and from 13.6 to $45.9 \mathrm{wt} \% \mathrm{TiO}_{2}$, Gieré et al., 1998), the identification of the present $\mathrm{Zr}$-rich silicate mineral as zirconolite is excluded. Instead, it appears to be an unidentified secondary $\mathrm{Zr}$-rich silicate mineral that may represent the major alteration and replacement of the precursor zirconolite. This is indicated by the changes in its composition marked by an increase in the amount of hydration $\left(\mathrm{H}_{2} \mathrm{O}\right), \mathrm{Si}$, and $\mathrm{U}$, and a decrease in the amount of $\mathrm{Ca}, \mathrm{Ti}, \mathrm{Nb}$, and $\mathrm{Fe}$ (Table 1). Some grains of the unidentified $\mathrm{Zr}$-rich silicate mineral show the common prismatic forms of the precursor zirconolite (Fig. 4). Other grains show high degree of metamictization and they are consequently altered to betafite. On the other hand, the zoning commonly observed in zirconolite is absent (Williams and Gieré, 1988, 1996; Bellatreccia et al., 1999). It should be noted that zirconolite has not been observed in the ore and is merely inferred from the secondary mineral assemblage considered to replace it.

It is suggested that the alteration of the unidentified $\mathrm{Zr}$-rich silicate mineral to betafite occurred during a period of time, depending on the hydrothermal solutions ac- 

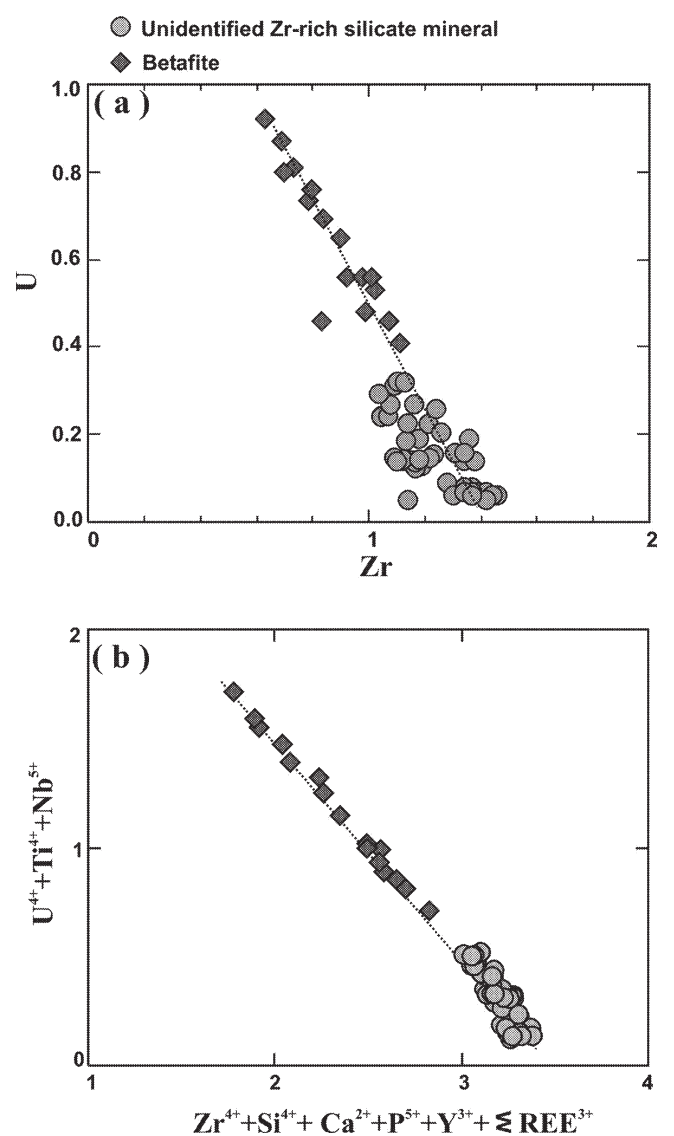

Figure 9. (a) Binary plots (apfu) of $\mathrm{Zr}$ versus $\mathrm{U}$. (b) $\left(\mathrm{U}^{4+}+\mathrm{Ti}^{4+}+\right.$ $\left.\mathrm{Nb}^{5+}\right)$ versus $\left(\mathrm{Zr}^{4+}+\mathrm{Si}^{4+}+\mathrm{Ca}^{2+}+\mathrm{P}^{5+}+\mathrm{Y}^{3+}+\Sigma \mathrm{REE}^{3+}\right)$. The negative correlation in both plots may reflect the dominant substitution during the alteration of the unidentified $\mathrm{Zr}$-rich silicate mineral to betafite. Cations are calculated on the basis of seven oxygen atoms.

tivity and the amount of available $U$ in these solutions. This results in changes in the stability of the unidentified $\mathrm{Zr}$-rich silicate mineral structure to the extent that it is replaced partly or completely by betafite of variable compositions (Figs. 4-6). The alteration of the unidentified $\mathrm{Zr}^{-}$ rich silicate mineral to betafite is indicated by a marked increase in the amount of $\mathrm{U}, \mathrm{Ti}$, and $\mathrm{Nb}$, and a decrease in the amount of $\mathrm{Zr}, \mathrm{Si}, \mathrm{Ca}, \mathrm{P}, \mathrm{Y}$, and $\mathrm{RREE}$ (Fig. 8). With more extensive alterations, the unidentified $\mathrm{Zr}$-rich silicate mineral became unstable and underwent re-equilibration with the fluid, leading to the removal of $\mathrm{Zr}$.

The transformation of the unidentified $\mathrm{Zr}$-rich silicate mineral into betafite generally involves at least two different mechanisms: (1) the dissolution of the unidentified $\mathrm{Zr}$-rich silicate mineral and the precipitation of a new phase representing betafite. This can happen by the penetration of hydrothermal fluids containing $\mathrm{U}, \mathrm{Ti}$, and $\mathrm{Nb}$ into the interior parts of crystals through cracks or zones that act as fluid conduits. These cracks can be produced by metamictization. Amorphous regions are more suscep- tible to fluid-alteration and dissolution than non-metamict regions. It is probable that such zones with high susceptibility, both within the crystal and at the rim, were fluidaltered to betafite at some time during the geological history of these crystals and (2) the ion exchange where $\mathrm{Zr}$ is replaced by uranyl ion (Fig. 9a) as well as other coupled substitution that could be inferred from the negative correlation between $\left(\mathrm{U}^{4+}+\mathrm{Ti}^{4+}+\mathrm{Nb}^{5+}\right)$ and $\left(\mathrm{Zr}^{4+}+\mathrm{Si}^{4+}+\mathrm{Ca}^{2+}\right.$ $+\mathrm{P}^{5+}+\mathrm{Y}^{3+}+\Sigma$ REE $^{3+}$ ) (Fig. 9b). Which of these reactions take place and to what extent depend mainly on the fluid composition and concurring reactions.

\section{Late low-temperature alteration stage}

In this stage, the previously formed betafite was subjected to low-temperature alteration and it was variably altered to liandratite. The effects of alteration are clearly observed in $\mathrm{Zr}$-poor betafite, which was completely broken down to liandratite, whereas $\mathrm{Zr}$-rich betafite was less affected. The presence of significant amounts of $\mathrm{Zr}$ considerably increases the radiation damage resistance of the material (Wang et al., 1999; Wang et al., 2000). Thermochemical and radiation damage studies of zirconolite and pyrochlore indicated that their stabilities were improved by the addition of $\mathrm{Zr}$ (Helean et al., 2004). This may explain the difficulty of dissolving the $\mathrm{Zr}$-rich betafite, which has a $\mathrm{Zr}$-bonded crystal structure, in low-temperature fluid. The secondary alteration of betafite is influenced by the grain size, prior radiation damage, microfracturing, volume and flow rate of the groundwater, and total exposure time. The geochemical alteration of betafite started with the leaching of $\mathrm{Si}, \mathrm{Ca}, \mathrm{Y}$, and RREs, followed by the recrystallization of liandratite from fluids rich in $\mathrm{U}, \mathrm{Nb}, \mathrm{Ti}$, and $\mathrm{Pb}$. The presence of an excess amount of $U$ in liandratite may point to another source of uranium in the solution, apart from betafite. This source could be coffinite and pitchblende, as reported by El Hazek (1968). Therefore, the uranium released from these primary uranium minerals is adsorbed by liandratite, where $\mathrm{U}$ is present in the fluid phase as the uranyl group $\mathrm{UO}_{2}^{2+}$. Many others natural betafite exhibit relatively low temperature, secondary alteration that ended by break down of leached betafite to liandratite + rutile, liandratite + rutile + uranpyrochlore, or rutile + uranpyrochlore (Lumpkin and Ewing, 1996). Uranpyrochlore is not observed in the present study, but rutile is present as separate grains or associated with betafite and liandratite.

Other previously reported secondary uranium minerals such as soddyite, kasolite, and uranophane (Attawiya, 1971; Osmond et al., 1999; Dawood et al., 2004) were also formed during this stage. The uranium series age of 87000 to 140000 years for these secondary uranium min- 


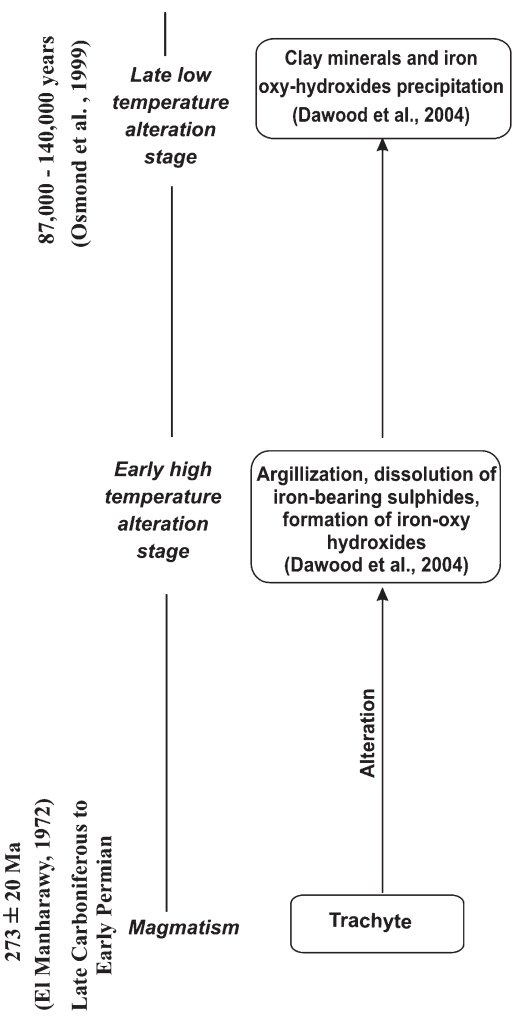

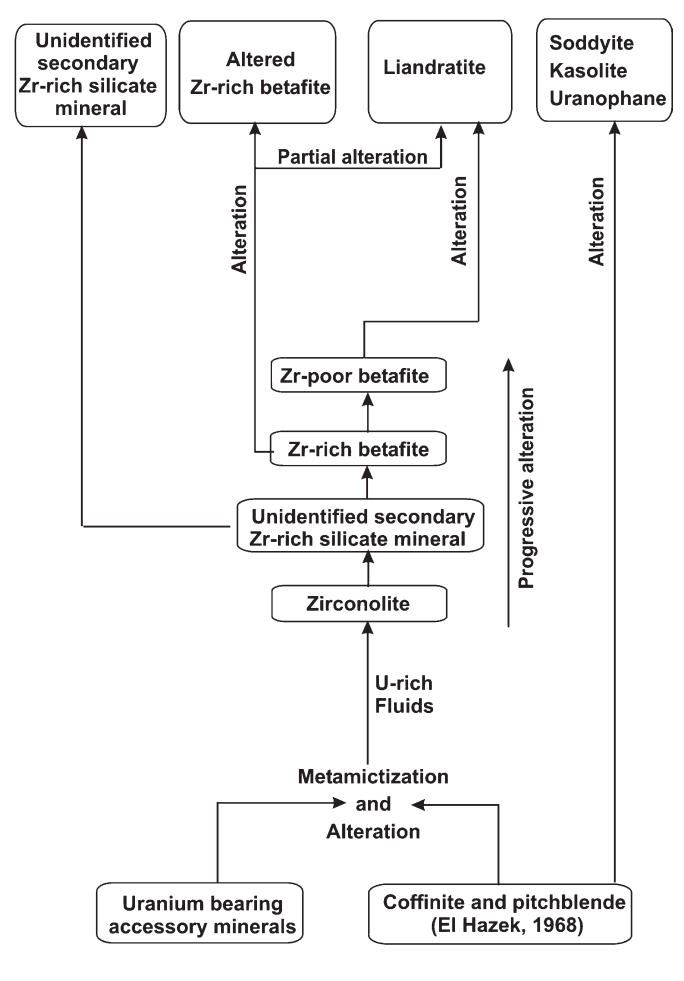

Figure 10. Genetic model for the high- and low- $T$ alteration of the $\mathrm{Zr}-$ and U-bearing minerals in the trachyte of the El Atshan area. Alteration of previously identified primary uranium minerals (coffinite and pitchblende) to soddyite, kasolite, and uranophane is also presented. erals has been reported by Osmond et al. (1999).

\section{GENETIC MODEL}

Based on field observations, mineralogical and geochemical data, and the previous geochronological data, a twostage metallogenetic model can be proposed for the alteration processes and the origin of uranium minerals in the trachyte of the El Atshan area (Fig. 10). The first stage is dominated by high-temperature fluid-rock interaction that released uranium from primary uranium minerals such as coffinite and pitchblende, as well as other accessory uranium-bearing minerals. The association of uranium-bearing minerals and fluorite in the fracture zones of the El Atshan area may reflect the role of fluoride complexes in the uranium solubility, mobility, and the formation of secondary uranium. The alteration of the unidentified secondary $\mathrm{Zr}$-rich silicate mineral to betafite occurred during this stage. This is indicated by the increase in the amount of $\mathrm{U}, \mathrm{Ti}$, and $\mathrm{Nb}$, and a decrease in the amount of $\mathrm{Zr}, \mathrm{Si}$, $\mathrm{Ca}, \mathrm{P}, \mathrm{Y}$, and $\Sigma$ REE. The single substitution of $\mathrm{U}^{4+} \leftrightarrow \mathrm{Zr}^{4+}$ and the coupled substitution of $\left(\mathrm{U}^{4+}+\mathrm{Ti}^{4+}+\mathrm{Nb}^{5+}\right) \leftrightarrow\left(\mathrm{Zr}^{4+}\right.$ $\left.+\mathrm{Si}^{4+}+\mathrm{Ca}^{2+}+\mathrm{P}^{5+}+\mathrm{Y}^{3+}+\Sigma \mathrm{REE}^{3+}\right)$ are inferred from the EPMA data. The stability of the unidentified $\mathrm{Zr}$-rich silicate mineral during alteration appears to depend on the composition of the associated fluids, especially on their uranium content.
The second alteration stage is dominated by low temperature alteration, as observed from the alteration of betafite to liandratite and the formation of other secondary uranium minerals such as soddyite, kasolite, and uranophane. By decreasing the temperature and increasing the oxygen fugacity $\left(f_{\mathrm{O}_{2}}\right)$ of the hydrothermal fluid, $\mathrm{U}^{4+}-$ fluoride was converted to uranyl fluoride complexes $\mathrm{UO}_{2} \mathrm{~F}_{3}^{-}$. When the activity of fluorine ions decreased due to a decrease in the temperature and an increase in the $\mathrm{pH}$ of the fluids, the uranyl fluoride complexes became unstable and decomposed, forming secondary uranium minerals (soddyite, kasolite, and uranophane) and precipitates of fluorite and calcite.

\section{CONCLUSION}

The conclusions of this study are as follows:

1. An unidentified secondary Zr-rich silicate mineral, betafite, and liandratite are identified for the first time in a trachyte of the El Atshan area, central Eastern Desert, Egypt.

2. The unidentified $\mathrm{Zr}$-rich silicate mineral is interpreted to be an alteration product of the precursor zirconolite during high- $T$ alteration. The resulting chemical formula for the $\mathrm{Zr}$-rich betafite is $\left(\mathrm{Si}_{1.45} \mathrm{U}_{0.18} \mathrm{Ca}_{0.32} \mathrm{~Pb}_{0.01} \mathrm{Nb}_{0.06}\right.$ $\left.\mathrm{Zr}_{1.18} \mathrm{Hf}_{0.01} \mathrm{Fe}_{0.06} \mathrm{Al}_{0.08} \mathrm{Ti}_{0.11} \mathrm{P}_{0.09} \mathrm{Y}_{0.05} \mathrm{REE}_{0.09}\right)_{\Sigma 3.7} \mathrm{O}_{7}$.

3. Betafite is enriched in $\mathrm{Zr}$, and the obtained chemical 
formula is ${ }^{A}\left(\mathrm{U}_{0.44} \mathrm{Ca}_{0.25} \mathrm{REE}_{0.05} \mathrm{Y}_{0.03} \mathrm{~Pb}_{0.02}\right){ }_{\Sigma 0.79}{ }^{B}\left(\mathrm{Si}_{0.79} \mathrm{Zr}_{0.69}\right.$ $\left.\mathrm{Ti}_{0.23} \mathrm{Nb}_{0.12} \mathrm{Al}_{0.06} \mathrm{Fe}_{0.05} \mathrm{P}_{0.03} \mathrm{~V}_{0.02} \mathrm{Hf}_{0.01}\right)_{\Sigma 2.0} \mathrm{O}_{7}$.

4. The role of high temperature alteration is confirmed from the corrosion of the unidentified $\mathrm{Zr}$-rich silicate mineral and $\mathrm{Zr}$-rich betafite. This alteration is indicated by an increase in the amount of $\mathrm{U}, \mathrm{Ti}$, and $\mathrm{Nb}$, and a decrease in the amount of $\mathrm{Zr}, \mathrm{Si}, \mathrm{Ca}, \mathrm{P}, \mathrm{Y}$, and $\Sigma \mathrm{REE}$. Single substitutions of $\mathrm{U}^{4+} \leftrightarrow \mathrm{Zr}^{4+}$ as well as a coupled substitution of $\left(\mathrm{U}^{4+}+\mathrm{Ti}^{4+}+\mathrm{Nb}^{5+}\right) \leftrightarrow\left(\mathrm{Zr}^{4+}+\mathrm{Si}^{4+}+\mathrm{Ca}^{2+}\right.$ $\left.+\mathrm{P}^{5+}+\mathrm{Y}^{3+}+\Sigma \mathrm{REE}^{3+}\right)$ are inferred from the EPMA data.

5. The calculated formula of liandratite is ${ }^{U}\left(\mathrm{U}_{1.35} \mathrm{Ca}_{0.41} \mathrm{~Pb}_{0.04}\right.$ $\left.\mathrm{REE}_{0.04} \mathrm{Y}_{0.01}\right)_{\Sigma 1.86}{ }^{N b}\left(\mathrm{Ti}_{0.67} \mathrm{Si}_{0.46} \mathrm{Nb}_{0.40} \mathrm{Zr}_{0.26} \mathrm{Fe}_{0.09} \mathrm{~V}_{0.08} \mathrm{Al}_{0.03}\right.$ $\left.\mathrm{Ta}_{0.01}\right)_{\Sigma 2.0} \mathrm{O}_{8}$. The average value of the $\mathrm{Nb}$-site total is identical to the stoichiometric value of two atoms per formula, whereas the value of the $U$-site total is significantly higher than the normal values that could be due to the addition of excess $U$ as well as substantial amounts of $\mathrm{Ca}$.

6. The role of the low temperature alteration in the formation of liandratite at the expense of betafite is also documented in the present study. It is evident that $\mathrm{Zr}$-rich betafite is more durable than $\mathrm{Zr}$-poor betafite and this may due to the strong $\mathrm{Zr}$ bonds with the crystal structure of $\mathrm{Zr}$-rich betafite.

\section{ACKNOWLEDGMENTS}

I thank Deutscher Akademischer Austauschdienst (DAAD) for supporting my post-doctoral visit to Tübingen University, Germany. I am grateful to W. Frisch, Tübingen University, for his assistance with the laboratory facilities and for fruitful discussions. I would also like to thank the reviewers for their insightful reviews, which helped in improving the original manuscript.

\section{SUPPLEMENTARY MATERIAL}

Color version of Figures 4, 5, and 6 is available online from http://www.jstage.jst.go.jp/browse/jmps.

\section{REFERENCES}

Attawiya, M.Y.A. (1971) Mineralogical and geochemical studies of the primary ore at El Atshan, Eastern Desert, Egypt. Master of Sciences Thesis, Ain Shams University, Cairo.

Ball, C.J., Buykx, W.J., Dickson, F.J., Hawkins, K., Levins, D.M., Smart, R.St.C., Smith, K.L., Stevens, G.T., Watson, K.G., Weedon, D. and White, T.J. (1989) Titanite ceramics for the stabilization of partially reprocessed nuclear fuel elements. Journal of the American Ceramic Society, 72, 404-414

Bellatreccia, F., Della Ventura, G., Caprilli, E., Williams, C.T. and Parodi, G.C. (1999) Crystal chemistry of zirconolite and calzirtite from Jacupiranga, Saõ Paulo, Brazil. Mineralogical Magazine, 63, 649-660.

Cámara, F., Williams, C.T., Della Ventura, G., Oberti, R. and Caprilli, E. (2004) Non-metamict betafite from Le Carcarelle (Vico volcanic complex, Italy): occurrence and crystal structure. Mineralogical Magazine, 68, 939-950.

Chan, H.M., Harmer, M.P., Smyth and D.M. (1986) Compensating defects in highly donor-doped $\mathrm{BaTiO}_{3}$. Journal of the American Ceramic Society, 69, 507-510.

Dawood, Y.H., Abd El-Naby, H.H. and Sharafeldin, A.A. (2004) Influence of the Alteration Processes on the Origin of Uranium and Europium Anomalies in Trachyte, Central Eastern Desert, Egypt. Journal of Geochemical Exploration, 88, 1527.

El Hazek, N.M.T. (1968) The primary ore at El Atshan and its physical and chemical properties (with special technological applications). Ph.D. Thesis, Ain Shams University, Cairo.

El Manharawy, M.S. (1972) Isotopic ages and origin of some uranium bearing volcanic rocks in Egypt. Master of Sciences Thesis, Cairo University, Cairo.

Gieré, R. and Williams, C.T. (1992) REE-bearing minerals in a Ti-rich vein from the Adamello contact aureole (Italy). Contribution to Mineralogy and Petrology, 112, 83-100.

Gieré, R., Williams, C.T. and Lumpkin, G.R. (1998) Chemical characteristics of natural zirconolite. Schweizerische Mineralogische und Petrographische Mitteilungen, 78, 433-459.

Harker, A. (1988) Tailored ceramics. In Radioactive waste forms for the Future (Lutze, W. and Ewing, R.C. Eds.). NorthHolland, Amsterdam, 335-392.

Hart, K., Mitamura, H., Vance, E., Banba, T. and Lumpkin, G. (1998) Final Report, Japan-Australia Co-operative Progaram on Research and Development of Technology for the Management of High Level Radioactive Wastes, 1985 to 1998 (ANSTO/E736), Australian Nuclear Science and Technology Organisation, Menai, Australia.

Hayakawa, I. and Kamizono, H. (1993) Durability of an $\mathrm{La}_{2} \mathrm{Zr}_{2} \mathrm{O}_{7}$ waste form in water. Journal of Materials Science, 28, 513517.

Helean, K.B., Navrotsky, A., Lian, J. and Ewing, R.C. (2004) Thermochemical investigation of zirconolite, pyrochlore and brannerite: Candidate materials for the immobilization of plutonium. In Scientific Basis for Nuclear Waste Management XXVII (Oversby, V.M. and Werme, L.O. Eds). Materials Research Society Proceedings, Pittsburgh, USA, 807, 297-302.

Hogarth, D.D. (1977) Classification and nomenclature of the pyrochlore group. American Mineralogist, 62, 403-410.

Hussein, H.A., Faris, M.I. and Assaf, H.S. (1970) Radioactivity and geology of El Atshan locality, Eastern Desert, Egypt. Arabian Journal of Nuclear Sciences and applications, 3, 6168.

Hussein, H.A. and El Kassas, I.A. (1972) Occurrence of some primary uranium mineralization at El Atshan locality, Central Eastern Desert. Egypt. Journal of Geology, 14, 97-110.

Johan, V. and Johan, Z. (1994) Accessory minerals in the Cínovec (Zinnwald) granite cupola, Czech Republic, Part 1: $\mathrm{Nb}^{-}, \mathrm{Ta}^{-}$ and Ti-bearing oxides. Mineralogy and Petrology, 51, 323343.

Lumpkin, G.R. and Ewing, R.C. (1985) Natural Pyrochlores: Analogues for Actinide Host Phases in Radioactive Waste Forms. In Scientific Basis for Nuclear Waste Management VIII Material (Jantzen, C.M., Stone, J.A. and Ewing, R.C. 
Eds.). Materials Research Society Proceedings, Pittsburgh, USA, PA 44, 647-54.

Lumpkin, G.R., Hart, K.P., McGlinn, P.J., Payne, T.E., Gieré, R. and Williams, C.T. (1994) Retention of actinides in natural pyrochlores and zirconolites. Radiochimica Acta, 66/67, 469-474.

Lumpkin, G.R. and Ewing, R.C. (1996) Geochemical alteration of pyrochlore group minerals: betafite subgroup. American Mineralogist, 81, 1237-1248.

Mücke, A. and Strunz, H. (1978) Petscheckite and liandratite, two new pegmatite minerals from Madagascar. American Mineralogist, 63, 941-946.

Obrenovic, M., El Kassas, I.A.E. and El-Amin, H.E. (1966) Report on the results of detailed exploratory mining works at the uranium deposit of Wadi El Atshan locality, central Eastern Desert. Cairo, Atomic Energy Establishment.

Osmond, J.K., Dabous, A.A. and Dawood, Y.H. (1999) U series age and origin of two secondary uranium deposits, central Eastern Desert, Egypt. Economic Geology, 94, 273-280.

Pan, Y. (1997) Zircon- and monazite-forming reactions at Manitouwadge, Ontario. Canadian Mineralogist, 35, 105-118.

Ressetar, R., Nairn, A.E.M. and Monrad, J.R. (1981) Two phases of Cretaceous-Tertiary magmatism in the eastern desert of Egypt: Paleomagnetic, chemical and $\mathrm{K}-\mathrm{Ar}$ evidence. Tectonophysics, 73, 169-193.

Ringwood, A.E., Kesson, S.E., Reeve, K.D., Levins, D.M. and Ramm, E.J. (1988) Synrock. In Radioactive Waste Form for the Future (Lutze, W. and Ewing, R.C. Eds.). North-Holland, Amsterdam, 233-334.

Rubin, J.N., Henry, C.D. and Price, J.G. (1993) The mobility of zirconium and other immobile elements during hydrothermal alteration. Chemical Geology, 110, 29-47.

Sayyah, T.A., Hashad, A.H. and El Manharawy, M.S. (1978) Radiometric $\mathrm{Rb} / \mathrm{Sr}$ isochron ages for Wadi Kareim volcanics. Arab Journal of Nuclear Sciences and applications, 11, 1-9.

Subramanian, M.A., Aravamudan, G. and Subba Rao, G.V. (1983) Oxide pyrochlores - a review. Progress in Solid State Chemistry, 15, 55-143.

Wang, S.X., Wang, L.M., Ewing, R.C., Was, G.S. and Lumpkin, G.R. (1999) Ion irradiation induced phase transformation of pyrochlore and zirconolite. Nuclear Instruments and Methods in Physics Research, B 148, 704-709.

Wang, S.X., Wang, L.M., Ewing, R.C., Govindan Kutty, K.V. (2000) Ion irradiation of rare-earth and yttrium-titanate-pyrochlores. Nuclear Instruments and Methods in Physics Research, B 169, 135-140.

Williams, C.T. and Gieré, R. (1988) Metasomatic zonation of REE in zirconolite from a marble skarn at the Bergell contact aureole (Switzerland/Italy). Schweizerische Mineralogische und Petrographische Mitteilungen, 68, 133-140.

Williams, C.T. and Gieré, R. (1996) Zirconolite: a review of localities worldwide, and a compilation of its chemical composition. Natural Historical Museum London, 52, 1-24.

Williams, C.T., Bulakh, A.G., Gieré, R. Lumpkin, G.R. and Mariano, A.N. (2001) Alteration Features in Natural Zirconolite from Carbonatites. Material Research Society Proceeding, Pittsburgh, USA, 663.

Manuscript received May 6, 2008

Manuscript accepted September 4, 2008

Manuscript handled by Takashi Murakami 